\title{
The Impact of Institutional Volatility on Financial Volatility in Transition Economies
}

\author{
Christopher A. Hartwell, PhD \\ Associate Professor \\ Kozminski University \\ Ul. Jagiellonska 57-59, 03-301 Warsaw, POLAND \\ Visiting Research Fellow \\ Bournemouth University \\ Bournemouth, UK \\ President \\ Center for Social and Economic Research (CASE) \\ Al. Jana Pawla II 61, Office 212, 01-031, Warsaw, POLAND
}

\begin{abstract}
What have been the determinants of financial volatility in the transition countries of Central and Eastern Europe and the former Soviet Union? This paper posits that institutional changes, and in particular the volatility of crucial institutions such as property rights, have been the major causes of financial volatility in transition. Building a unique monthly database of 20 transition economies from 1991-2017, this paper applies the GARCH family of models to examine financial volatility as a function of institutional volatility. The results show that more advanced institutions help to dampen financial sector volatility, while institutional volatility feeds through directly to financial sector volatility in transition. Democratic changes in particular engender much higher levels of volatility, while property rights are sensitive to the metric used for their measurement.
\end{abstract}

Keywords: Institutions, financial sector, volatility, property rights, transition, GARCH JEL Codes: G20, O43, P30

\section{POSTPRINT VERSION}

The published Version of Record is available here: 10.1016/j.jce.2017.11.002

(C) 2018 This postprint version is made available under the CC-BY-NC-ND 4.0 license http://creativecommons.org/licenses/by-nc-nd/4.0/ 


\section{Introduction}

Policy uncertainty as a determinant of financial and economic outcomes, while not a new phenomenon (Ferderer and Zalewski 1994), has enjoyed a renaissance in the economic literature recently. Work spearheaded by Baker et al. (2016) has highlighted the different dimensions of such uncertainty, exploring how governmental gyrations can feed through to the real economy. Extensions to this research by Boutchkova et al. (2012), Pastor and Veronesi (2013), and Brogaard and Detzel (2015) have applied the same conceptual framework to explore the effects of policy uncertainty on stock market volatility. These recent explorations have empirically demonstrated the link between political instability and volatility, with Boutchkova et al. (2012) noting that policy uncertainty creates a country-specific systematic risk. Along these same lines, Pastor and Veronesi (2013) also show how policy uncertainty not only creates risk but has an amplified effect in countries with weak economic conditions, introducing an element of feedback from uncertainty to risk and back again.

While this burgeoning literature has thus far examined manifestations of policy changes (generally derived from news-based indices), the findings from Boutchkova et al. (2012) and Pastor and Veronesi (2013) suggest that other types of uncertainty beyond mere news announcements may be more pervasive in determining systematic levels of financial volatility. In particular, there is a chance that an economy may be undergoing institutional volatility, when policies are no longer mere adjustments to current paths but instead signal a re-evaluation of the building blocks of an economy. In fact, this idea of "institutional uncertainty" should be felt first and foremost in financial markets, which have been shown to be very sensitive even to news (Engle and $\mathrm{Ng} 1993$ ); large changes in institutions should have correspondingly larger 
effects. Institutional volatility would thus be a better metric of systemic risk than news or discrete political changes.

How would threats to and reforms of basic institutions such as the political system or property rights then translate into financial volatility? This paper is motivated by this research question, as the idea of institutional volatility and its relation to financial markets is a notable gap in the extant literature. A possible reason for this oversight is the reality that institutional volatility is rarely observed, given that institutional changes are meant to take place over a long period of time (as opposed to financial sector movements, which are very high-frequency). Indeed, institutions are characterized by time-invariance and semi-permanence, a trait which allows them to both be plausibly assumed as exogenous over a short time-frame and also separated out from policies and other attributes of an economy. Institutional changes, when they do occur, either happen over a long period of time through very gradual evolution (as in the case of religious dogma) or in a sudden structural break. From an econometric standpoint, in the first instance, quantification of institutions would show only the most minute changes (if any) over a long period, while in the second, large changes may be missed in highly aggregated data.

The transition experience in the countries of Central and Eastern Europe (CEE) and the former Soviet Union (FSU) are an exception to this rule, as they have not had the luxury of institutional stability over the past quarter-century. The change of institutions from communist-era to capitalist ones occurred in a compacted time frame and was observed in real-time, necessarily leading to several episodes of institutional change, occurring at different times and at different speeds. This experience affords us the opportunity to understand the effects of this institutional volatility, as changes in fundamental institutions such as democracy or the building of institutions such as property rights could have significantly impacted a country's systematic 
risk profile. In fact, the relationship of institutional volatility to financial volatility could be even more pronounced in the transition context, as changes in financial sector institutions in transition occurred in tandem with broader institutional changes throughout an economy. Understanding these linkages, it is not unreasonable to assume that the broader institutional environment could both influence financial sector development and influence the incidence of volatility.

Given this reality, this paper focuses on the countries of CEE and FSU as a laboratory to examine the effects of institutional changes on financial markets. Going beyond the policy uncertainty concept, I make a contribution to both the institutional and financial market literature by empirically identifying the impact of deeper institutional changes on financial risk. Assembling a unique database of monthly institutional changes from 1991 to 2017, this paper applies the GARCH family of models to ascertain the impact of institutions on financial volatility in 20 transition economies. The results confirm previous research that more advanced institutions, specifically democratic accountability and property rights, are good for financial markets. More importantly, this analysis also demonstrates that institutional volatility feeds through directly to financial sector volatility, with democratic volatility have a consistent negative impact.

The rest of the paper proceeds as follows. Section 2 discusses the literature behind institutional volatility, while Section 3 describes the empirical model and identification strategy. Section 4 discusses the unique dataset created for the paper and diagnostics utilized, while Section 5 presents estimation results on the series of GARCH-family models utilized. Section 6 concludes with implications and future avenues for research. 


\section{Institutions and Financial Volatility: What is the Link?}

\subsection{Stock Markets and Institutions}

A voluminous literature exists in finance and economics on the determinants of stock market volatility, with these determinants loosely grouped into three separate areas:

- The intrinsic or actualized attributes of stock markets that make them susceptible, such as systematic risk, size or capitalization (Bekaert and Harvey 1997), turnover (Andersen 1996), leverage (Christie 1982), and other attributes of a particular stock exchange (Gabaix et. al 2006);

- Domestic and international macroeconomic factors and policies (Schwert 1989), including growth (Beltratti and Morana 2006), inflation (Flannery and Protopapadakis 2002), credit (Gourinchas, Valdes, and Landerretche 2001), overall macroeconomic health (Errunza and Hogan 1998), and other business cycle factors exogenous to the stock exchange (Bollerslev and Zhou 2006); and

- Behavior and performance of other stock markets (King and Wadhwani 1990, Forbes and Rigobon 2002, Beirne et. al 2009, and literally hundreds of other papers), as a method of importing either stability or volatility exogenous to both specific stock exchanges and specific countries.

With regard to the relationship between institutions and the financial sector, however, research has been conducted mainly at a higher level, focusing on overviews that answer the question if institutions influence financial sector development and activity. The overwhelming consensus is "of course," with work such as Beck and Levine (2008) concluding that legal origins can account for differences in property rights regimes and thus the development of a country's financial sector. Similarly, Demirgüç-Kunt and Levine (1996) find that countries with welldeveloped institutional systems tend to have large and liquid stock markets and Durham (2002) 
notes that rule of law and institutions more broadly support financial development. Chinn and Ito (2006) also find that general institutional quality indicators, such as rule of law and bureaucratic quality, support successful financial sector development greater than financial sector-specific institutions (such as transparency of accounting procedures).

At a more disaggregated level, the literature has shied away from more specific classifications of "institutions," preferring to examine them ad hoc rather than delineating institutions by their function and then tracing out how said institution would theoretically influence financial markets. This approach misses the variegated nature of institutions and, in particular, the reality that there is a distinct difference between how a political institution would affect financial development versus an economic one. As Hartwell (2013) notes, economic institutions are designed or arise to maximize the utility of principals in the economic sphere, by solely influencing and mediating economic outcomes pertaining to distribution of resources; on the other hand, political institutions pertain to distribution of political power and, while they may have economic impact as a second-order effect, they are not explicitly designed to influence incentives. Thus, an economic institution may rely on political institutions (like the judiciary) but is concerned with economic matters such as incentives, coordination, information, or transaction costs. Conversely, political institutions are concentrated on the rules and procedures of political power, such as election rules, constraints on the executive, and parliamentary oversight, the rules of a different game than economic institutions. Clearly, each of these types of institutions would influence financial sectors differently, and would have effects both direct and indirect.

To dig deeper, there are specific types of institutions under these headings which also could be expected to have a greater influence on financial markets. As the sine qua non of economic 
institutions, property rights have been proven empirically to be a foundation for transition dynamics (Hartwell 2013), economic growth (Torstensson 1994, Acemoglu and Johnson 2005, Asoni 2008, and many others), and, most importantly for our purposes, the development of an effective financial sector (Clague et al. 1999, Andrianaivo and Yartey 2009).

The reason for the association between the level of a country's property rights and its financial sector development is clear: more secure property rights, in addition to providing the basis for greater savings (and thus lending), also allow for the use of collateral in financing (as well as increasing the value of that collateral, see Claessens and Laeven 2003). Moreover, property rights define the contractual relations in an economy, and higher levels of such rights mean less risk of contractual non-compliance (Clague et al. 1999). Additionally, property rights create incentives for investment (Besley 1995) that would contribute to financial sector development, as firms seek out better financing vehicles to allow them take advantage of market opportunities. Claessens and Laeven (2003) provide some evidence for this view, finding that property rights improve asset allocation in the financial sector, which then in turn leads to positive effects on growth in sectoral value. Johnson et al. (2002) also note that secure property rights encourages firms to reinvest profits within their own country, providing needed capital to financial markets, while low levels of property rights increase retained earnings and skew financial intermediation away from capital markets and towards banks.

Unlike the large theoretical and empirical literature on this particular economic institution and financial markets, there is comparatively less written on the impact of political institutions on the functioning of stock exchanges. Keefer (2008) provides an excellent overview of the extant research, noting that a consensus has been reached on the importance of political checks and balances for financial sector development, but also noting that political competition and 
credible commitment may dominate in terms of influencing financial sectors. Haber (2008) also notes that democracy may limit predatory behavior by elites, limiting their ability for financial repression. However, there is also evidence that democracy is not essential for a functioning financial sector, as Rajan and Zingales (2003) note that financial repression might actually be favored by democracies, sold to citizens as a means of consumer protection but is in reality a way to protect incumbent rents. Yang (2011a) provides evidence that levels of democracy also have little effect on broader financial sector development (also shown in Miletkov and Wintoki [2009]) and, importantly for this paper, no correlation with stock market development.

\subsection{Institutions and their Volatility}

Almost all of the quantitative institutional literature noted above has focused on institutions at their levels or, in rare instances, annual changes, while trying to ascertain the effect of institutions on financial markets (of course, there is a large theoretical literature on institutional change, but this is rarely tested empirically). But institutions, despite their semi-permanent nature, do change, and these changes should have effects in both financial markets and the real economy. Moreover, institutional change may not be linear but may be subjected to a series of starts and stops, creating volatility, unpredictability, and uncertainty in an economy and across socioeconomic relations (Gilles et al. 2015).

Indeed, the research that has been done examining institutional volatility has been focused on the quantification of institutional instability on economic growth, rather than on financial sector outcomes. Brunetti and Weder (1998) focus on changes in national-level political institutions, including constitutional changes and probability of institutional shifts (based on survey data), finding that constitutional changes (i.e. political volatility) are negatively correlated with 
growth. In a similar vein, Svensson (1998) also examines political institutional volatility, modeling the effect of political institutions on economic ones (in this case, property rights). His results point to a negative effect on investment, with the probability of an imminent political change (derived from a probit model) harming property rights formation, which then in turn feeds through to investment decisions (Yang (2011b) also finds that normal democratic processes tend to increase macroeconomic instability). Berggren et al. (2011) take this examination even further to model the effects of institutional "instability" on growth, using coefficients of variation from a set of institutional measures constructed by principal components analysis (PCA) to proxy for instability over a five-year period. Using a GLS estimator with fixed-effects and controlling for other macroeconomic influences, their results are "context dependent:" in particular, they find that instability in legal and policy institutions in rich countries actually contributes significantly to higher growth rates, while instability of social institutions is a drag on growth across all countries.

Beyond the linkages between growth and institutional volatility, the economics research tends to thin out, with other disciplines only taking up the slack marginally. For example, Chung and Beamish (2005) examine the dynamic nature of institutions in the context of multinational decisions in emerging economies, finding that firms that are either wholly-owned subsidiaries or majority-domestic joint ventures weather periods of institutional volatility better than mostly "foreign" firms. Other researchers have come at the issue of institutional volatility from either a law or political science perspective; Gallo and Alston (2008), for example, place the difficulties in Argentina's banking system since 1949 as a function of the breakdown of judicial independence and purge of $80 \%$ of the Supreme Court justices in 1947. Similarly, Stern et al (2002) comes closer to the issue of financial sector performance and institutional volatility, but 
their focus is less on the impact of institutional volatility on the financial sector as the secondorder impact on governmental crisis management in the Baltic countries.

\section{$2.3 \quad$ Institutional Volatility $\rightarrow$ Financial Volatility}

Given the large amount of evidence linking institutional quality to financial sector development and, in many cases, performance, it stands to reason that volatile institutional changes would also translate through to financial sector outcomes. But the slow-paced nature of institutional change (and the difficulty of quantifying it) have pushed researchers interested in volatility towards examining "policy uncertainty" as a determinant of financial sector outcomes. A somewhat first-order solution to a second-order issue (after all, policies are the inputs that can shape institutions and their development, either explicitly or implicitly), the policy uncertainty literature has laid a theoretical groundwork for the effects of institutional volatility, with papers such as Rodrik (1991), Aizenman and Marion (1993), Pastor and Veronesi (2013), and Baker et al. (2016) focusing on the feed-through of instability to the real economy via expectations and investment decisions. Similarly, work from Brogaard and Detzel (2015) examines 21 developed and developing economies and finds that their measure of economic policy uncertainty depresses stock market returns and increases risk.

Taking this uncertainty approach to the next level means consolidating the previous literature to understand that uncertainty regarding specific institutions (i.e. property rights and democracy) will translate directly into financial volatility. From an information perspective, news and policies may convey information regarding the future path of institutional development, but legislative changes and institutional reforms are likely to have a much larger effect than mere news. Indeed, in the transition context, news and policy shifts actually may 
have an enormous impact on institutional development, which then would send signals to the markets regarding the state of property rights or democracy in a country.

As an example, volatility of property rights can affect financial volatility over time through many channels. At an aggregate level, Angelopoulos et al. (2011) show how property rights in Mexico had a direct influence on the evolution of macroeconomic stability in a country, noting that this in turn influenced financial volatility. With stable property rights engendering higher levels of macroeconomic stability on average, a country should then also see dampened volatility in its financial markets. But in relation to the information channel, French and Roll (1986), DeLong et al. (1990) and Morck et al. (2000) focus on the effects that secure property rights have on facilitating information for risk arbitrage. Morck et al. (2000:216) note that "inadequate protection for property rights could make informed risk arbitrage in their stock markets unattractive" as arbitrageurs are unable to keep the fruits of their arbitrage labor, thus depriving the market of informed traders and creating far too much noise. In such an environment, information scarcity can exacerbate volatility, making markets even more susceptible to rumors, political changes, or other news that might have been appropriately hedged with better property rights (De Long et al. 1990). However, where property rights are secure, information regarding firm-specific risk is valued accordingly, meaning that every bit of bad news or financial shock need not necessarily lead to panic nor should spillover effects of firm-specific financial failures be magnified throughout the market. In this sense, property rights perform an analogous function in financial markets to Baumol's (1990) assertion that property rights enable entrepreneurs to survive technology shocks, acting as an information buffer against exogenous financial shocks. 
Similar to the information argument is a question of credible commitment. If we define property rights as a hedge against government expropriation (Acemoglu and Johnson 2005), an environment of stronger and more stable rights means less of a chance of a catastrophic financial outcome in the economy caused by government (e.g. nationalization), that would in turn induce elevated levels of volatility. Where property rights are continually being redefined, as in the early stages of a transition economy or during momentous political changes, financial markets are less likely to see these rights as a credible and valid protection against government depredation. With worries about political interference in markets amplified by a lack of established property rights, financial markets may then overshoot beyond fundamentals or continue to see heightened levels of volatility for longer periods of time than in a secure property rights environment.

On the other hand, there are also theoretically plausible scenarios where property rights can correlate with high volatility. A key tenet of ownership is the right to dispose of assets as one sees fit. Given that property rights make ownership easier, in an atmosphere of financial uncertainty or exogenous financial socks, it stands to reason that property rights may actually act as a lubricant for volatility; firms or investors would then be able to unload their assets more quickly than in an environment where exchange is more difficult. Thus, the security of property rights may actually contribute to an increase in turnover, which may magnify volatility. In addition, building on the Morck et al. (2000) thesis noted above, secure property rights may create more informed traders and capitalize information more easily into stock prices. But in an environment where other supporting institutions are absent, such as sound monetary institutions or executive constraints, knowledge may actually play a role in exacerbating volatility. In an environment where bad news abounds, informed traders could act as a signaling device to the rest of the market, creating volatility where before was an (unstable and sub- 
optimal) equilibrium. In the case of a country with no good news to trade on, ignorance might be bliss.

While we noted above that political institutions and their lack of correspondence to financial sector development, there is a voluminous literature related to political volatility and financial volatility, albeit related to political events and not political institutions. For example, work from Bialkowski et al. (2008) and Boutchkova et al. (2012) examines elections and their financial impact, concluding that the variance of returns from a country's major index doubles during an election week. Hartwell (2017) also looks at the effects of various types of political instability on financial markets in transition, finding that elections have a significant role to play in creating volatility. However, the idea that sustained or unexpected institutional volatility (after all, elections are planned months, if not centuries, in advance), can have immediate effects on financial performance throughout the economy has remained relatively unexplored.

\section{Empirical Strategy}

\subsection{Identification Strategy}

The empirical strategy for this paper seeks to link together the various strands of literature noted in the previous section, modelling the effects of two specific types of institutional volatility on financial sector outcomes. The basic model for this examination is:

$$
\text { (1) } y_{i t}=\mu_{i t}+\varepsilon_{t}
$$

Where:

$$
\text { (2) } \mu_{i t}=\alpha+\beta I N S T_{i t-1}+\gamma M A C R O_{i t-1}+\rho y_{i t-n}+\epsilon_{i t}
$$

And

$$
\text { (3) } \varepsilon_{i t}=\sigma_{i t} Z_{i t}
$$


This model relates financial market outcomes (Y) to institutions (INST), macroeconomic conditions (MACRO), an $n$-order autoregressive process, and idiosyncratic processes related to financial market volatility ( $\varepsilon$, more on this below).

The Y variable in Equation 1 will be proxied by two separate measures. The first, standard in the literature (starting with Merton (1980) and Perry (1982)), is stock market returns, expressed as the log difference of the returns in the stock market index of country $i$ between day $t$ and day $t-1:$

$$
\text { (4) } y_{i t}=\left(\sum_{t=1}^{N t}\left[\log \left(p_{t}\right)-\log \left(p_{t_{-1}}\right)\right] * 100\right)
$$

This metric, used inter alia by Baillie and Degennaro (1990), Chiang and Doong (2001), and Nikkinen et al. (2008), is aggregated monthly so as to comport with the highest-frequency institutional data available (see below). This indicator as a measure of financial market health has the benefit of long histories in the transition economies (in some cases, such as the Czech Republic, 285 separate monthly observations are available) but is unfortunately not available for all of the countries of Central/Eastern Europe and the former Soviet Union (a complete description of all data sources is shown in the Data Appendix, Table A.1).

From this return data, a volatility series can be generated utilizing standard financial econometric measures, to understand the relationship between volatilities. The estimator of choice for the volatility modeling is the autoregressive conditionally heteroskedastic (ARCH) family of models, which have been utilized to investigate the effects of financial volatility in a large and well-established literature (Engle 1982, Hayo and Kutan 2005, and Wu and Shea 2011 are but a few examples). ARCH models have positives that recommend them to the 
application of institutional changes, especially in the context of transition economies. In particular, institutional shocks can display a high degree of persistence (if not an outright structural break) and have periods of large and volatile movements, followed by periods of "normalcy," only to be followed again by high volatility. ${ }^{1}$

Despite these positive attributes, $\mathrm{ARCH}$ modelling for institutional changes is relatively rare. Asteriou and Price (2001), Henisz (2004), Jayasuriya (2005), Klomp and De Haan (2009), and the immediate predecessors of this current paper, Campos and Karanasos (2008) and Campos, Karanasos, and Tan (2012), are the notable exceptions (see Table 1 for a summary of these papers). For our purposes, theoretically, institutional shocks in transition should exhibit asymmetric effects that would not be captured in a simple GARCH specification, with negative institutional shocks having a greater (negative) effect on financial volatility than positive shocks of the same magnitude would (Malik 2011). Indeed, it can be theorized that institutional volatility would have a similar effect to bad news, with "bad" institutional changes having much "worse" effects on volatility (Engle and Ng 1993), but in a much more persistent and deeper manner than mere bad news. This reality would recommend either the exponential generalized autoregressive conditional heteroskedasticity (EGARCH) model of Nelson (1991), the GJR-GARCH model of Glosten, Jagannathan and Runkle (1993), or, as in Campos and Karanasos (2008), one of the power-ARCH (PARCH or APARCH) models as the preferred approach. Each of these models defines (if slightly differently) the $\epsilon$ term shown in Equations

\footnotetext{
${ }^{1}$ While GMM estimators are equipped to handle conditional heteroskedasticity, as Fleming (1998) notes, timeseries volatility data have a high degree of serial correlation that may generate spurious results in a GMM framework. In this data especially (and as noted below), there is high persistence of volatility, meaning longer lags of variables would be needed as valid instruments; as Tauchen (1986: 397) notes, however, the bias of GMM rises as more instruments based on deeper lags of variables are introduced, leading to estimates concentrating "around biased values [while] confidence intervals become misleading." Finally, diagnostic tests using a "systemGMM" approach with this sizeable dataset inevitably resulted in an over-proliferation of instruments even after collapsing instruments and restricting lags, a problem that Roodman (2009) notes leads to imprecise estimates of the weighting matrix.
} 
1 and 3 to introduce the leverage effects in the conditional variance. For example, the APARCH model frames volatility in the conditional variance as:

(5) $\sigma_{i, t}^{\delta_{i}}=\alpha_{0}+\sum_{j=1}^{q} \alpha_{i, j}\left(\left|\varepsilon_{i, t-j}\right|-\gamma_{i, j} \varepsilon_{i, t-j}\right)^{\delta}+\sum_{k=1}^{p} \beta_{i, k} \sigma_{i, t-k}^{\delta_{i}}+\eta \chi_{i t}^{\prime}$

Where $\gamma_{i, j}$ is a leverage term which captures any asymmetric effects of shocks to the system, the first summation is the lag of the residuals of power $\delta$ from the mean equation (the ARCH term, weighted by the coefficient $\alpha_{i, j}$ and with the restriction that $\alpha \geq 0$ ) and the second summation is the previous period's forecast variance (the GARCH term, weighted by $\beta_{i, k}$ and also restricted at $\beta \geq 0$ ). As Ding et al. (1993) prove and as Laurent (2004) notes, this model nests up to seven variations of the GARCH models within it depending upon the $\delta$ term (e.g., a standard GARCH model has $\delta=0$ and $\gamma=0$ ).

In a different vein, the EGARCH approach models volatility via a logarithmic transformation, making it a more flexible model than GJR-GARCH (in that it requires no constraints to keep the volatility effect non-negative) but otherwise is similar to the APARCH model in that it models volatility as a function of previous period (log squared) variance forecasts (the GARCH term) and previous innovations (the $\mathrm{ARCH}$ term). ${ }^{2}$ If we rearrange equation 3 so that

$$
\text { (6) } z_{i t}=\varepsilon_{i t} \sigma_{i t}^{-1}
$$

We can express the EGARCH model as:

$$
\text { (7) } \begin{gathered}
\ln \left(\sigma_{i, t}^{2}\right)=\omega_{0}+\sum_{i=1}^{p} \zeta_{i} \log \left(\sigma_{i, t}\right)^{2}+\rho_{i, j}\left(\sum_{j=i}^{q}\left[\left|z_{i, t-j}\right|+E\left|z_{i, t-j}\right|\right]+\gamma z_{i, t-j}\right) \\
+\eta \chi_{i, t}^{\prime}
\end{gathered}
$$

To each of these standard equations can be added additional variables, in our case, metrics to capture the volatility of institutions; shown as the vector of institutional changes $\chi_{i t}^{\prime}$ in

\footnotetext{
${ }^{2}$ As can be seen in Equation 7, the EGARCH model deviates from the APARCH family as it measures conditional variance as an explicit multiplicative function of lagged innovations.
} 
Equations 5 and 7, this vector includes both the level measurement of the institutional variable (property rights and democracy) and the volatility measurement of the institutional variable as part of the conditional variance of returns. Based on the idiosyncrasies of this particular data and given the similarity in their treatment of volatility shocks, post-estimation statistics such as the Akaike Information Criterion (AIC) and the Bayesian Information Criterion (BIC) will be used to determine which approach models the conditional volatility more effectively.

The approach taken here will also deviate from earlier studies by using a panel-GARCH model in the vein of Cermeno and Grier (2006), who note, "to study the determinants and real effects of uncertainty in the developing world, we need a panel GARCH model." Panel-GARCH has the merit of augmenting the relative paucity of observations per country but also capturing the heightened effects that are anticipated in an emerging or transition framework; as Lee (2010:143) notes, “panel GARCH models entail potential efficiency gains in estimating the conditional variance and covariance processes by incorporating relevant information about heterogeneity across economies as well as their interdependence." The panel utilized here is a pooled set of countries facing independent innovations; diagnostic testing using country fixedeffects dummies found no appreciable difference in significance but instead just made convergence more difficult.

As a check on the volatility measure derived from absolute returns, an additional measure of financial volatility will also be utilized for robustness tests. Realized volatility, an increasinglypopular but long-pedigreed measure of financial instability, will also be included to verify the results obtained from modeling of returns. For this examination, and as in Christensen and Prabhala (1998), Andersen et al. (2003), Ludvigson and Ng (2007), and Beine et al. (2010), realized volatility is defined as the standard deviation of the daily index return: 


$$
\text { (8) } \sigma^{2}=\sum_{t=1}^{N}\left(r_{i t}-\bar{r}_{i t}\right)^{2}
$$

Where $r$, daily returns (defined as $\left.\log \left(\mathrm{p}_{\mathrm{t}} / \mathrm{p}_{\mathrm{t}-1}\right)\right)$ is demeaned, squared, and then summed over the month for each country. For estimation purposes, this metric has different properties from absolute returns, and diagnostics revealed it follows a heteroskedastic, AR(1) process. As this indicator allows for "normal" panel data econometric testing without deriving a volatility process, I follow the approach of Hartwell (2014) and fashion a fixed-effects model with realized volatility on the left-hand side and the same institutional and control variables as shown in prior equation on the right-hand side. Standard OLS estimation is used for this specification but with Driscoll-Kraay (1998) standard errors to allow for controlling countrylevel effects (and time-invariant characteristics), in addition to correcting for heteroskedasticity, autocorrelation, and contemporaneous spatial correlation across countries. Moreover, this approach is suitable given the properties of Driscoll-Kraay errors, which requires a long time-series, as the high-frequency nature of this data means that every country has well over the "safe" limit of $\mathrm{T}=50$ required for Driscoll-Kraay estimation. Finally, the use of fixed-effects in a Driscoll-Kraay pooled specification has the added bonus of requiring only weak exogeneity of the regressors, which is likely to be the case here (Vogelsang 2012).

\subsection{Measuring Institutional Volatility}

As noted above, the two institutions to be tested in the empirical specification are property rights and democracy. Two separate indicators will be utilized to test the effects of property rights on volatility, each with its own advantages and drawbacks. The first indicator will measure potential property rights, encompassing legislation regarding various facets of property rights (on the theory that, if the law were followed to its letter and its spirit, property rights would attain a maximum amount of protection available under the particular law). For the econometric examination below, the metric used to capture these potential rights is the 
International Country Risk Guide (ICRG) measure "investment profile," which covers contract viability and threat of expropriation. There has been extensive use of this metric in the literature as a proxy for property rights, including Knack and Keefer (1995), Knack (1996), and Svensson (1998), and more recently in a financial sector context by Durnev et al. (2009), Ali et al. (2010), Dutta and Roy (2011), and Lin et al. (2012). With good coverage back to pre-transition for many countries, the ICRG investor protection indicator has an added advantage of use in other studies as a broad proxy for institutional quality more generally (see, for example Busse and Hefeker 2007 or Catrinescu et. al 2009).

However, the ICRG indicator is, according to the PRS group, "made on the basis of subjective analysis of the available information" on a country, and as such relies heavily on legislation and other input indicators (Voigt 2013). The second indicator for property rights thus recognizes the reality that legislative frameworks in countries in flux, such as in transition economies, rarely encompass the reality of property rights and administration often diverges from legislation. This measure, one of realized property rights, is "contract intensive money" (CIM), an indicator used by inter alia Clague et. al (1996, 1999), Dollar and Kraay (2003), Compton and Giedeman (2011), and Hartwell (2013). CIM measures the proportion of money held outside the formal banking sector as a proportion of all money:

$$
\text { (9) } \frac{\left(M_{2}-C\right)}{M_{2}}
$$

Where M2 is a measure of broad money and $\mathrm{C}$ is the amount of money held outside formal deposit institutions. Under the concept of contract-intensive money, greater property rights would manifest itself as larger amounts of money held inside the formal banking sector. While this objective indicator may capture more than pure property rights protection, ${ }^{3}$ the use of

\footnotetext{
${ }^{3}$ It has been suggested (see Brown, Carmignani, and Fayad 2013) that contract-intensive money may be a better indicator for financial depth rather than property rights. However, I disagree with this assertion due to the frequency of the data - in a transition economy, property rights may be in a state of flux, with various initiatives
} 
contract-intensive money not only avoids some of the critiques of a subjective measure such as that leveled by Voigt (2013); as Clague et. al 1996 demonstrate, variation in the CIM indicator across countries mirrors actual changes in institutions and policies, and thus is empirically more reliable than subjectively derived data on property rights enforcement (see Figure 1 for the path of contract intensive money in each country).

Given that property rights are a measure of a key economic institution, inclusion of a measure of political institutions will also shed light on the institutional determinants of volatility and how political institutions interact with economic ones. For this, I use the ICRG indicator for "democratic accountability" as a proxy for political institutions and how they may influence financial volatility (following Campos and Karanasos (2008)). The inclusion of democracy is of course an imperfect catch-all for political institutions, especially given that it is theoretically unclear why democracy would lead to better (worse) outcomes with financial volatility; moreover, previous work in growth economics has shown a negative effect of democracy (Hartwell 2013). ${ }^{4}$ However, given the paucity of monthly political institutional data, this remains one of the best proxies available for ascertaining the state of a country's political institutions and their effect on financial markets (Akitoby and Stratmann 2010).

These measures of both economic and political institutions will enter the mean equation at their levels at a lag, in order to avoid simultaneity issues (see Equation 2). However, as the real

changing the overall perception of rights protection in a short period of time. In contrast, financial depth is a slower-moving creature that may change radically as new legislation or instruments are introduced, but in general doesn't exhibit the same volatile shifts that basic institutions in flux would. Thus, saying that financial depth changes from month to month and can be captured by this indicator is a much bigger reach than noticing the reaction of the populace to changes that can directly affect their property.

${ }^{4}$ This also enters under the heading of "agenda for future research," as there may be better monthly metrics to measure political institutions. Other metrics that have been utilized in other papers, however, such as the ICRG's measure of the military in politics (used by Miletkov and Wintoki 2017) are unsuitable for the set of transition economies examined in this paper. The search continues. 
purpose of this current examination is to understand institutional volatility, volatility metrics based on the institutional variables just noted will also be also constructed. Following an approach used by Berggren et al. (2011), I use a 6-month rolling standard deviations of each institutional variable. Constructed via Stata's "rollstat" routine, this method results in a variable at the end of the window which encompasses the standard deviation of the institutional metric for that country over the previous three to six months (creating a "realized volatility" metric for institutions). With a moving window across each panel (and, in many instances, more coverage of institutional measures than stock market ones), this calculation preserves a full data series of institutional volatility.

\subsection{Controls}

As explanators for other variables that may be influencing financial volatility, the MACRO vector shown in Equation 2 above includes a set of macroeconomic variables drawn from the long literature relating macroeconomics to financial volatility (see especially the comprehensive examinations of Garcia and Liu (1999) and Christiansen et al. (2012)). A complete description of all variables is shown in Table 1.

- Inflation is included, as in Christiansen et al. (2012), acting as a proxy for general macroeconomic policy instability. Inflation has also been shown to negatively impact financial sector performance (Boyd, Levine, and Smith 2001), as well as being correlated (Chen, Roll, and Ross (1986), Engle and Rangel (2008), and Corradi, Distaso, and Mele (2013)) with greater financial volatility. To account for hyperinflationary episodes, the inflationary variable is transformed as in Staehr (2005) as $\log$ (inflation rate year-on-year+100). 
- Economic Growth is a proxy for the overall macroeconomic health of an economy. As Engle and Rangel (2008: 1209) note, “countries experiencing low or negative economic growth observe larger expected volatilities than countries with superior economic growth." As used in Engle, Ghysels, and Sohn (2013) and scores of other papers, economic activity is proxied here by the percentage change in industrial production indices month-to-month. ${ }^{5}$

- Exchange rates: As noted in Hsing and Hsieh (2012) in the transition context, the net impact of exchange rate appreciation is unclear, but their empirical results showed a consistent negative relationship between exchange rate changes and stock market returns in Poland. As in Ludvigson and $\mathrm{Ng}$ (2007), here we use monthly change in the real effective exchange rate.

- EU Accession: Finally, transition economies are in reality a heterogeneous group. Indeed, of the group of economies examined here, exactly half (ten) implemented reforms that qualified for accession to the European Union. Given that these countries based their legal and regulatory reforms on the European model, EU accession could have created an exogenously-determined improvement in institutional quality and stability that would be different from those countries not seeking EU accession. For the purposes of this examination, a dummy was created that took the value of 0 for each month that a country was not in the EU and a value of 1 from the moment it acceded and every month thereafter. As a control, an alternate dummy was used, taking the value of 1 for every period if the country ever joined the EU (i.e. Bulgaria would be coded as

\footnotetext{
${ }^{5} \mathrm{~A}$ major caveat regarding industrial production should be considered, as transition economies, where the move is away from Soviet-style heavy industry, should necessarily see a slowing of industrial production (perhaps permanent) as the economy reorients itself. For the purposes of this dataset, however, the creation of financial exchanges occurred generally after the bulk of the transformational recession was completed, meaning that industrial production can be safely included.
} 
a 1 in 1998 even though it did not join the EU until 2008), to capture institutional convergence effects. ${ }^{6}$

Each of these indicators will be included in the empirical analysis at their levels in the conditional mean to show effects on stock market returns. As with the institutional variables, volatility metrics constructed of 6-month rolling standard deviations are used in the conditional variance equation, to match macroeconomic volatility with financial volatility.

\subsection{Data}

Given the smaller sub-set of transition countries that have functioning stock exchanges, this restricts the data somewhat to 20 countries over various time periods starting from 1989 and ending in May 2017: Belarus, Bosnia, Bulgaria, Czech Republic, Croatia, Estonia, Hungary, Kazakhstan, Kyrgyzstan, Latvia, Lithuania, (Former Yugoslav Republic of) Macedonia (FYROM), Mongolia, Poland, Romania, Russia, Serbia (and Montenegro, until 2005), Slovakia, Slovenia, and Ukraine. The countries included are a healthy mix of EU accession and non-EU accession states (split evenly down the middle), as well as a collection of large and small economies and states at various stages of development. These countries are also characterized by differing sizes of their capital markets, with some striking differences; for example, the value of all shares traded on the Tallinn Stock Exchange in 2004 was only 5\% of that traded in Prague. ${ }^{7}$ In other countries, the number of listed domestic companies are much smaller than in others, but not necessarily in the way one would expect. Indeed, countries very open to foreign investment such as the Czech Republic have far fewer domestic firms listed than countries such as Croatia (15 versus 185 in 2015, according to the World Bank).

\footnotetext{
${ }^{6}$ Additional permutations of this dummy were attempted in diagnostic regressions, including a dummy if EU access was one year away, two years away, etc. None of these dummy variables proved significant and thus are not included here.

${ }^{7}$ Based on World Federation of Exchanges data.
} 
Given this diversity of capital markets, a plausible argument can be made that less-important stock exchanges would have less of an effect on overall financial volatility or a country's risk profile. However, while the stock exchanges examined here may have differing levels of importance to their national economies, that does not vitiate the thesis of this paper, namely that institutional changes may harm ways in which the financial sector examines risk. In fact, for countries which have thinner capital markets (say, a Kyrgyz Republic or a FYROM), institutional changes should be more pronounced, as the lack of liquidity and arbitrage opportunities will make them highly susceptible to institutional changes. Such an effect would be even more pronounced in countries where the state has a much larger role in the economy (e.g. Belarus), and, given that these economies would also have greater sensitivity to institutional changes originating from the top, the financial sector could represent the canary in the coal mine for an economy risk profile. Put another way, small capital markets may not capture the total economic effect of changes in a country's risk due to institutional volatility, but they are even more likely to be affected by institutional change. Thus, retaining stock market changes as a measure of financial volatility is quite appropriate to tease out these institutional effects.

The institutional and macroeconomic data for these countries came from a large variety of sources, including from Bloomberg and CEIC for stock market returns; M2, currency outside depository corporations, and some industrial production variables from either the IMF's International Financial Statistics (IFS) or from the central banks of each transition economy (often obtained via arduous excel manipulation) or central statistical bureaus (also often obtained on paper and entered in manually); interest rate data from Eurostat, the European 
Central Bank, and country national banks; exchange rate data from Darvas (2012); and property rights and democracy data from ICRG, as noted above.

Diagnostics on the dataset (Table 2) also confirm the presence of significant conditional heteroskedasticity across variables, especially seen in the Lagrange Multiplier (LM) test of Engle (1982) for ARCH effects. Moreover, the high levels of leptokurtosis in the institutional data points strongly towards use of a model incorporating either a Student $t$ distribution or Generalized Error Distribution (GED), as opposed to a Gaussian (normal) one, in order to capture the "fat tails" of the institutional variables (Bollerslev 1987, Nelson 1991, and Bollerslev, Engle, and Nelson 1994). Finally, examination of the autocorrelation and partial autocorrelation functions of the returns and volatility variables show the persistence of the dependence over time; in particular, the returns data shows extensive persistence through the first lag, meaning an AR(1) model is most appropriate (as shown in Equation 2, as diagnostics regarding model using at various $\mathrm{AR}(\mathrm{p})$ lags also showed that AIC and Schwarz Bayesian Information (SBIC) criterion were minimized with an AR(1) model).

\section{Results}

\subsection{GARCH Results}

The results of the effect of both institutional levels and institutional volatility on financial volatility are shown in Tables 3 and 4 . While the GARCH family of models are powerful in terms of their versatility in modeling volatility, they are fragile in terms of convergence due to the gradient-like algorithm used to solve the log-likelihood maximization, especially in the 
presence of many (and changing) covariates (Zumbach 2000). For this reason, as the set of controls change, the preferred model (in terms of AIC/BIC minimization and simple convergence ability) from the alphabet soup of ARCH models may change. As noted above, however, models utilizing a leverage term were consistently favored, including the EGARCH model of Nelson (1991), the Power-GARCH model of Higgins and Bera (1992), the Asymmetric Power-GARCH model of Ding et al. (1993), the Nonlinear Asymmetric PowerGARCH of Bollerslev et al. (1994), or the Threshold GARCH model of Zakoian (1994).

The baseline regressions shown in Table 3 examine the effect of medium-term (6-month) institutional volatility on financial returns and volatility. As noted above, in each regression, the macroeconomic controls were also retained in the conditional variance as a volatility metric (the same as the institutional variables, as a 6-month rolling standard deviation), but are not shown for space considerations. Columns 1 and 3 of Table 3 utilize contract-intensive money as a proxy for property rights in the conditional mean and variance, while Columns 2 and 4 use the ICRG investor protection measure; the difference between the first two regressions and the last two regressions is a shift in the measure of EU membership, from the dummy marked at the time of membership and afterwards to the time in which an EU Association Agreement was in effect but EU Accession had not occurred.

The results from this examination are consistent across all specifications, with legislated property rights being positively correlated with stock returns in transition while democracy is bad for the stock market. There is a split difference on realized property rights (contractintensive money), shown as highly important and positive for returns when the EU Accession dummy is used but insignificant when the Association Agreement dummy is included. Perhaps more importantly, an examination of the conditional variance equations tells an interesting tale, 
as legislated property rights also contribute significantly to more volatility, in line with the theoretical supposition noted above. Somewhat surprisingly, the variance of property rights (for either proxy) is statistically insignificant over a 6-month window. By contrast, democracy at its level dampens volatility in 3 of the 4 specifications, but the volatility of democracy unequivocally and significantly correlates with much higher levels of financial volatility. A plausible explanation here is perhaps that markets sense that property rights can only be defended successfully from a democratic regime, and thus the political system in transition is more important than such rights for ensuring stability.

Another explanation for these results is one of measurement error regarding property rights changes, in that perhaps what matters most over longer time horizons is not the magnitude of institutional changes, but the persistence of institutional change. To test this proposition, Columns 5 and 6 of Table 3 use a slightly different indicator of institutional volatility, constructing a sum of squares of changes in realized property markets over a longer period (12 months). The results, with two specifications to show the two different EU dummies (and using an asymmetric non-linear power-GARCH as in Bollerslev et al. [1994]), confirm the earlier regressions on the role of democracy. More importantly, however, the results also show that persistent and cumulative property rights volatility over a 12-month rolling window can indeed create significantly more financial volatility. In fact, the effect of the 12-month volatility of realized property rights dwarfs any other effect economically (while being significant at the 5\% level when paired with the EU Association Agreement dummy).

\subsection{Robustness and Sensitivity Tests}

The baseline regressions show the effect of democracy on financial volatility in transition to be much larger than volatility of property rights. However, if change continues to occur and 
build cumulatively in the application of property rights, it too can have a deleterious effect on stock market stability. This section tests if these results hold in the face of a battery of different internal and external controls.

A crucial issue which may influence financial markets in transition is not only domestic conditions but global economic trends; indeed, the time frame covered in this paper spans several periods of global recession and crisis, and it is plausible that the relation between market volatility and institutions could be driven by global conditions and not necessarily institutional change (Beirne et. al 2009 noted that nearly half of all domestic stock market volatility in emerging markets can be explained by spillovers). The first robustness test is thus an inclusion of a dummy for the global financial crisis, coded as 1 from every month between July 2007 and June 2009 and zero otherwise, following the dating of the crisis from the St. Louis Federal Reserve Bank as used in Leiss et al. (2015). Shown in Columns 1 and 2 of Table 4, the global financial crisis dummy is highly significant in reducing returns and increasing volatility; at the same time, however, democratic volatility continues to also heighten volatility along with levels of legislated property rights. ${ }^{8}$ As in the earlier regressions, the value of realized property rights has little effect on volatility.

Beyond the major financial cataclysm of the financial crisis, perhaps it was more the daily give and take of global markets which exert a great influence on transition markets. In order to account for this possibility within the transition space (and to avoid a possibly enormous omitted variable), I further include two variables to proxy for "normal" global volatility: first, the price of gold as a metric of world financial instability more generally, included at its levels

\footnotetext{
${ }^{8}$ The model including EU Accession was retained for the robustness tests, given its slightly better performance in the baseline regressions. Results for the EU Association Agreement, not reported here but available from the author, also did not change the baseline results.
} 
in the conditional mean equation and its volatility month-on-month in the conditional variance equation; and secondly, the US S\&P 500 index, as a check for US market volatility, included at its levels in the mean equation and its volatility in the conditional variance equations. ${ }^{9}$

The results of this inclusion are shown in Table 4, Columns 3 through 6 , and the use of either proxy enters as highly significant (economically and econometrically) for determining returns in transition economies, while only S\&P volatility correlates with financial volatility. With the inclusion of these global indices, both realized and legislated property rights are a significant and positive contributor to stock market returns in transition, while democracy continues to dampen returns on average in three out of four specifications (Columns 3, 4, and 5). With regard to volatility, democratic volatility continues to correlate with significantly higher volatility, even as the S\&P volatility has the dominant effect in determining home-market volatility. Indeed, the inclusion of these global drivers of volatility improves the models overall (as measured by log-likelihood and information criteria), and should be taken as excellent proof (if not definitive) of the impact of institutions on financial volatility.

As a final robustness test, and a way to overcome the possible sensitivity of GARCH models, realized volatility is also included to tease out institutional volatility effects. Becoming standard in the literature, the use of realized volatility (RV) as a dependent variable has the advantage of being an unbiased estimator, and as Andersen et al. (2003) show, in some specifications may perform better than GARCH-modeled volatility. Using a fixed-effects Driscoll-Kraay estimation, Table 5 shows what is basically a different modelling approach to the conditional variance equations from Tables 3 and 4. Using the final model from Table 4, including S\&P

\footnotetext{
${ }^{9}$ The volatility for both gold and the S\&P index was calculated as a realized volatility and done in the manner of Equation 7 above.
} 
volatility, the results appear to place stronger significance on property rights volatility than the corresponding GARCH modeling shown above, while confirming the role of democratic volatility. Realized property rights at its level appears to ensure marginally less realized volatility, but volatility of such rights, as measured by contract-intensive money, over a 6month window also correlate with greater volatility. When considering legislated rights, there is a more statistically significant but smaller economic effect dampening volatility, but the effect of democratic volatility is stronger. Taking into account global trends, the EU factor, and macroeconomic variables, this additional test shows that institutional volatility continues to influence trends in financial markets in transition.

\section{Conclusions}

This paper has explored several related questions regarding institutional change and financial volatility, using novel methods, indicators, and high-frequency data. The results have mirrored earlier research, which found that better institutions in transition economies supplemented financial sector development. However, going beyond previous research, this study broke new ground in examining the effects of institutional volatility on financial volatility using GARCH and standard econometric modeling. The application of this modeling to institutional change showed that institutional effects manifest themselves quite strongly on financial markets, albeit in different manners. In particular, it was shown that democratic volatility led to high levels of financial volatility over the medium-term, while property rights volatility had a somewhat more muted effect, dependent upon which aspect of property rights was being examined. Indeed, the divergence between realized and legislated property rights shows the difficulty in quantifying institutions, but are provided to give a more holistic view of which facet of property rights affects financial volatility and in what manner. And somewhat surprisingly, property rights 
themselves appeared to contribute to volatility, an effect which could be considered salutary, as new market participants entered for the first time. But on the whole, better and more stable institutions appeared to make financial stability more likely.

The extensions to this work are legion, including the application of GARCH-MIDAS models, given the differential frequency of data and also of speed of movement of indicators. Moreover, this work has only concentrated on two windows of institutional and macroeconomic volatility; the permutations of time-frames and their combinations is endless. Also, as noted earlier, a logical extension to this work is expanding the set of controls for the models contained in this paper, with the first step exploring high-frequency indicators to proxy for financial liberalization as a control for institutional and policy effects. Continued research into the quantification of institutions, especially objective indicators for both economic and political institutions at a high frequency, will also contribute to our knowledge of the effects of institutional volatility on financial markets; perhaps an approach similar to the work done by Hayo and Kutan (2005) is called for, proxying political volatility by its appearance in the media rather than as a direct measurement.

Last but not least, of course, this paper has only focused on transition economies, due to the idiosyncratic nature of institutional change in these countries. A welcome addition to the literature would be an expansion of this analysis to other (including developed) countries undergoing institutional changes, to assess the impact of institutional volatility on these economies. In one sense, all economies are "transition" economies, as their institutions and policies are changing, and expansion of this current work to OECD and emerging market economies would take this reality into account. 
Figure 1 - Contract-Intensive Money in Transition, 1990-2016

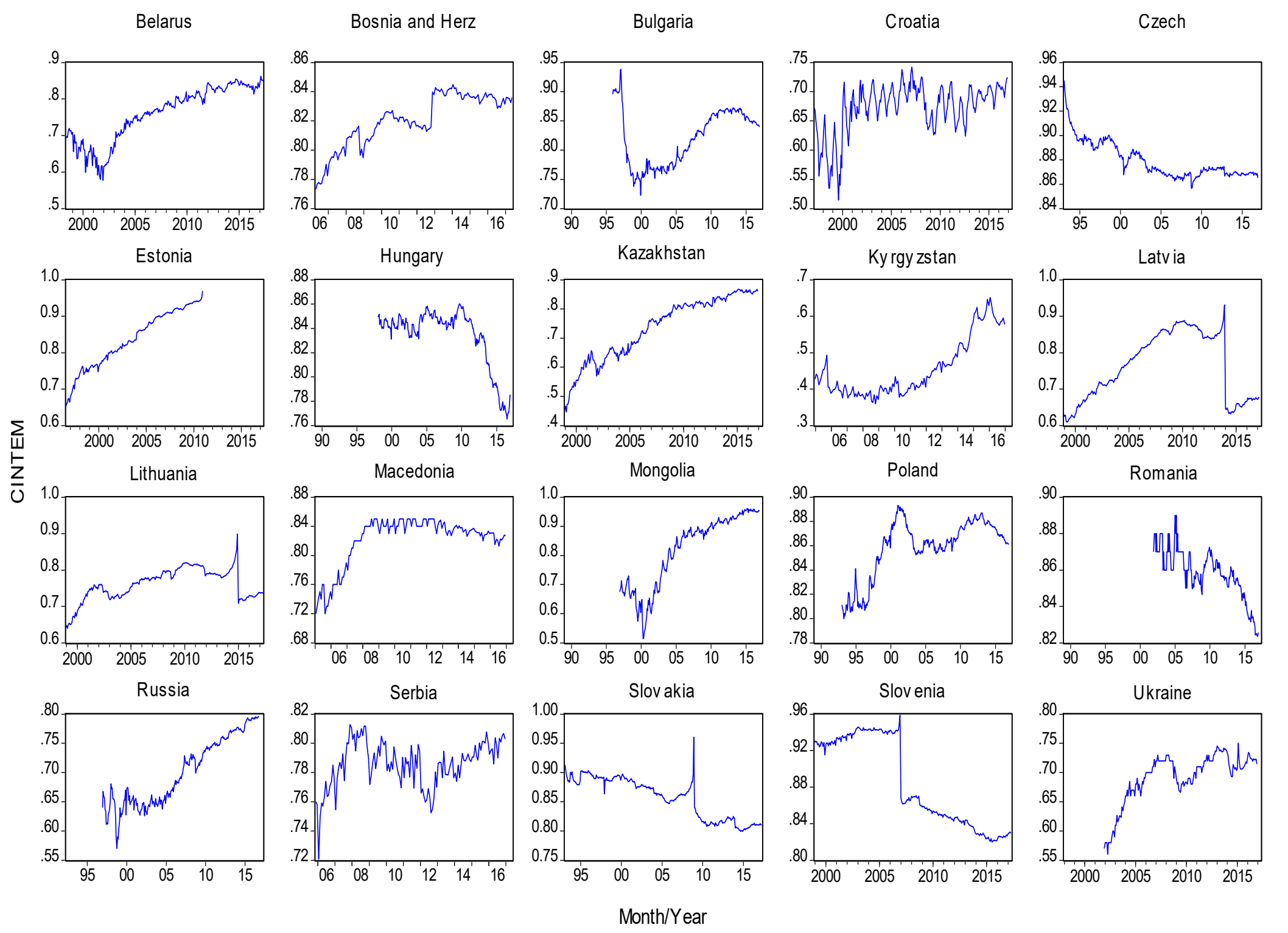


Table 1 - Recent Research in GARCH Modelling and Institutions

\begin{tabular}{|c|c|c|}
\hline Author(s) & Method & Results \\
\hline Asteriou and Price (2001) & $\begin{array}{l}\text { GARCH and GARCH in means } \\
\text { (GARCH-M) }\end{array}$ & $\begin{array}{l}\text { Constructing a principal component measure of political instability from } \\
\text { various indicators including strikes and terrorism, they find that political } \\
\text { instability has a highly negative, significant, and persistent effect on GDP } \\
\text { growth in the UK. }\end{array}$ \\
\hline Henisz (2004) & GARCH & $\begin{array}{l}\text { Henisz uses a GARCH }(1,1) \text { model to construct volatilities of nine separate } \\
\text { fiscal policy indicators on a panel of } 172 \text { countries over } 18 \text { years. The policy } \\
\text { volatility measure is then used as the dependent variable in a number of } \\
\text { regressions to ascertain the effects of political institutions on policy volatility. }\end{array}$ \\
\hline Jayasuriya (2005) & EGARCH and TGARCH & $\begin{array}{l}\text { Jayasuriya uses asymmetric modelling to examine the relationship between } \\
\text { stock market volatility and institutional quality in } 18 \text { emerging markets, in } \\
\text { particular investor protection and rule of law. She finds that quality of } \\
\text { institutions (levels) correspond with lower volatility after financial } \\
\text { liberalization. }\end{array}$ \\
\hline $\begin{array}{l}\text { Campos and Karanasos (2008) and } \\
\text { Campos, Karanasos, and Tan (2012) }\end{array}$ & Power-ARCH (PARCH) & $\begin{array}{l}\text { They find that both formal (government changes) and informal (assassinations) } \\
\text { political volatility affected growth in Argentina over 1896-2000, with informal } \\
\text { volatility having a greater short-run and direct effect. }\end{array}$ \\
\hline Klomp and de Haan (2009) & GARCH & $\begin{array}{l}\text { Klomp and De Haan utilize GARCH }(1,1) \text { modeling in order to isolate their } \\
\text { political uncertainty variables, but otherwise include these variables in a } \\
\text { standard GMM and mean group series of panel data estimations. }\end{array}$ \\
\hline
\end{tabular}


Table 2 - Descriptive Statistics

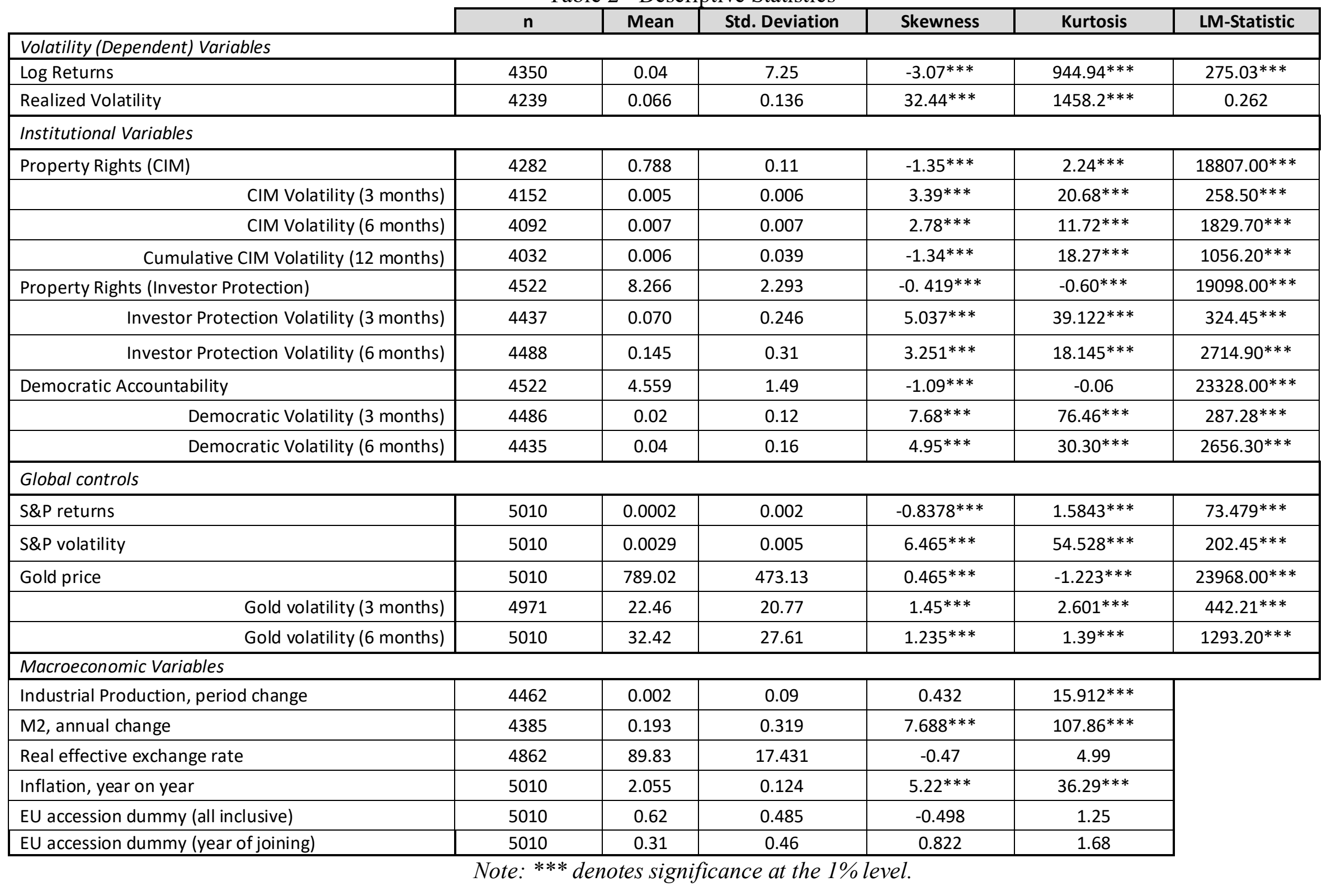


Table 3 - GARCH Regressions of Stock Market Returns vs. 6-month Institutional Volatility

\begin{tabular}{|c|c|c|c|c|c|c|}
\hline & \multirow{3}{*}{\begin{tabular}{|c|}
1 \\
AR(3)- \\
APGARCH(1,1)
\end{tabular}} & \multirow{3}{*}{$\begin{array}{c}2 \\
\operatorname{AR}(1)- \\
\operatorname{EGARCH}(1,1)\end{array}$} & \multirow{3}{*}{$\begin{array}{c}3 \\
A R(1)- \\
\operatorname{PGARCH}(2,2)\end{array}$} & \multirow{3}{*}{$\begin{array}{c}4 \\
A R(3)- \\
\operatorname{EGARCH}(1,1)\end{array}$} & \multirow{3}{*}{\begin{tabular}{|c|}
5 \\
AR(3)- \\
NPGARCH(1,1)
\end{tabular}} & \multirow{3}{*}{$\begin{array}{c}6 \\
\text { AR(3)- } \\
\text { NPGARCH }(1,1)\end{array}$} \\
\hline & & & & & & \\
\hline & & & & & & \\
\hline \multicolumn{7}{|l|}{ Conditional Mean Equation } \\
\hline \multicolumn{7}{|l|}{ INSTITUTIONAL VARIABLES } \\
\hline Property rights (contract-intensive money) & $\begin{array}{c}0.07 \\
23.46^{* * *}\end{array}$ & & $\begin{array}{c}0.008 \\
0.31\end{array}$ & & $\begin{array}{l}-0.01 \\
1.69 *\end{array}$ & $\begin{array}{r}-0.07 \\
1.28\end{array}$ \\
\hline Property rights (investor protection) & & $\begin{array}{c}0.006 \\
21.79 * * *\end{array}$ & & $\begin{array}{c}0.006 \\
12.42^{* * *}\end{array}$ & & \\
\hline \multirow[t]{2}{*}{ Democratic accountability } & -0.005 & -0.006 & -0.006 & -0.01 & -0.007 & -0.009 \\
\hline & $8.74^{* * *}$ & $8.34^{* * *}$ & $1.75 *$ & $14.04^{* * *}$ & $3.71 * * *$ & $1.69 *$ \\
\hline \multicolumn{7}{|l|}{ MACROECONOMIC CONTROLS } \\
\hline Inflation, year on year & $\begin{array}{c}-0.004 \\
3.59 * * *\end{array}$ & $\begin{array}{c}-0.002 \\
1.79 *\end{array}$ & $\begin{array}{c}-0.004 \\
3.55^{* * *}\end{array}$ & $\begin{array}{c}-0.001 \\
1.05\end{array}$ & $\begin{array}{c}-0.004 \\
1.39\end{array}$ & $\begin{array}{c}-0.003 \\
2.64 * * *\end{array}$ \\
\hline Exchange rate change (month on month) & $\begin{array}{c}0.0200 \\
3.91^{* * *}\end{array}$ & $\begin{array}{c}0.01 \\
3.84^{* * *}\end{array}$ & $\begin{array}{c}0.0200 \\
4.20^{* * *}\end{array}$ & $\begin{array}{c}0.01 \\
3.46^{* * *}\end{array}$ & $\begin{array}{c}0.02 \\
2.89^{* * *}\end{array}$ & $\begin{array}{c}0.02 \\
3.77^{* * *}\end{array}$ \\
\hline Change in industrial production & $\begin{array}{c}-0.15 \\
2.43^{* *}\end{array}$ & $\begin{array}{c}-0.17 \\
2.79 * * *\end{array}$ & $\begin{array}{c}-0.17 \\
2.53 * *\end{array}$ & $\begin{array}{c}-0.17 \\
2.62 * * *\end{array}$ & $\begin{array}{l}-0.14 \\
1.69^{*}\end{array}$ & $\begin{array}{l}-0.14 \\
2.18^{* *}\end{array}$ \\
\hline M2 annual change & $\begin{array}{c}0.24 \\
4.44^{* * *}\end{array}$ & $\begin{array}{c}0.17 \\
6.01^{* * *}\end{array}$ & $\begin{array}{c}0.24 \\
4.53^{* * *}\end{array}$ & $\begin{array}{c}0.19 \\
3.23^{* * *}\end{array}$ & $\begin{array}{c}0.14 \\
2.36^{* *}\end{array}$ & $\begin{array}{c}0.14 \\
3.34^{* * *}\end{array}$ \\
\hline EU Accession dummy & $\begin{array}{c}-0.02 \\
4.54^{* * *}\end{array}$ & $\begin{array}{c}-0.02 \\
2.26^{* *}\end{array}$ & & & $\begin{array}{r}-0.02 \\
1.47\end{array}$ & \\
\hline \multirow[t]{2}{*}{ EU association agreement in force } & & & -0.03 & -0.03 & & -0.03 \\
\hline & & & 0.97 & 1.11 & & 1.04 \\
\hline \multirow[t]{2}{*}{ C } & 0.006 & 0.02 & 0.05 & 0.02 & 0.10 & 0.13 \\
\hline & $2.22 * *$ & $4.93 * * *$ & $1.92 *$ & $5.50 * * *$ & $9.57^{* * *}$ & $3.19^{* * *}$ \\
\hline \multicolumn{7}{|l|}{ Conditional Variance Equation } \\
\hline Property Rights (CIM) & $\begin{array}{l}0.81 \\
1.21\end{array}$ & & $\begin{array}{l}0.45 \\
0.81\end{array}$ & & $\begin{array}{c}1.41 \\
2.49^{* *}\end{array}$ & $\begin{array}{c}0.89 \\
1.68^{*}\end{array}$ \\
\hline
\end{tabular}




\begin{tabular}{|c|c|c|c|c|c|c|}
\hline & 1 & 2 & 3 & 4 & 5 & 6 \\
\hline & $\begin{array}{c}\text { AR(3)- } \\
\text { APGARCH(1,1) } \\
\end{array}$ & $\begin{array}{c}\text { AR(1)- } \\
\operatorname{EGARCH(1,1)}\end{array}$ & $\begin{array}{c}\text { AR(1)- } \\
\text { PGARCH(2,2) }\end{array}$ & $\begin{array}{c}\text { AR(3)- } \\
\text { EGARCH(1,1) }\end{array}$ & $\begin{array}{c}\text { AR(3)- } \\
\text { NPGARCH(1,1) }\end{array}$ & $\begin{array}{c}\text { AR(3)- } \\
\text { NPGARCH(1,1) }\end{array}$ \\
\hline SD of Property Rights (CIM), 6 months & $\begin{array}{l}-1.75 \\
0.23\end{array}$ & & $\begin{array}{l}2.28 \\
0.37\end{array}$ & & & \\
\hline Cumulative Property Rights Changes (CIM), 12 months & & & & & $\begin{array}{l}2.17 \\
1.73^{*}\end{array}$ & $\begin{array}{c}2.56 \\
2.03^{* *}\end{array}$ \\
\hline Property Rights (Investor Protection) & & $\begin{array}{c}0.01 \\
3.48^{* * *}\end{array}$ & & $\begin{array}{c}0.01 \\
2.45^{* *}\end{array}$ & & \\
\hline SD of Property Rights (Investor Protection), 6 months & & $\begin{array}{r}-0.02 \\
0.51\end{array}$ & & $\begin{array}{r}-0.01 \\
0.23\end{array}$ & & \\
\hline Democratic Accountability & $\begin{array}{l}-0.05 \\
1.66^{*}\end{array}$ & $\begin{array}{c}-0.008 \\
1.41\end{array}$ & $\begin{array}{c}-0.08 \\
2.87^{* * *}\end{array}$ & $\begin{array}{l}-0.01 \\
2.22 * *\end{array}$ & $\begin{array}{r}-0.05 \\
1.63\end{array}$ & $\begin{array}{c}-0.08 \\
2.78 * * *\end{array}$ \\
\hline SD of Democratic Accountability, 6 months & $\begin{array}{c}0.62 \\
2.13^{* *}\end{array}$ & $\begin{array}{c}0.18 \\
2.60^{* * *}\end{array}$ & $\begin{array}{c}0.59 \\
2.31^{* *}\end{array}$ & $\begin{array}{c}0.19 \\
2.62^{* * *}\end{array}$ & $\begin{array}{l}0.52 \\
1.84^{*}\end{array}$ & $\begin{array}{c}0.58 \\
2.05^{* *}\end{array}$ \\
\hline Leverage effect & $\begin{array}{c}1.14 \\
4.59 * * *\end{array}$ & $\begin{array}{c}2.94 \\
15.61^{* * *}\end{array}$ & $\begin{array}{c}0.89 \\
4.65^{* * *}\end{array}$ & $\begin{array}{c}3.01 \\
15.39^{* * *}\end{array}$ & $\begin{array}{c}-0.01 \\
3.09 * * *\end{array}$ & $\begin{array}{c}-0.44 \\
2.64^{* * *}\end{array}$ \\
\hline n & 3152 & 3412 & 3152 & 3412 & 3150 & 3150 \\
\hline $\begin{array}{l}\text { Macro volatility controls in variance equation? } \\
\text { Log Likelihood }\end{array}$ & $\begin{array}{c}\text { yes } \\
-1502.597\end{array}$ & $\begin{array}{c}\text { yes } \\
1585.38\end{array}$ & $\begin{array}{c}\text { yes } \\
-1518.069\end{array}$ & $\begin{array}{c}\text { yes } \\
-1589.37\end{array}$ & $\begin{array}{c}\text { yes } \\
-1453.37\end{array}$ & $\begin{array}{c}\text { yes } \\
-1462.24\end{array}$ \\
\hline AIC & 0.9680 & 0.9422 & 0.9772 & 0.9451 & 0.9380 & 0.9430 \\
\hline Distribution & Student's T & Student's T & Student's T & Student's T & Student's T & Student's T \\
\hline
\end{tabular}

Dependent variable is log stock market returns, with model choice shown above each column of results. Note: absolute values of t-stats are under the coefficients, with * signifying significance at the $10 \%$ level, ** at 5\% and *** at the $1 \%$ level. The complete set of macroeconomic variables utilized in the conditional mean equation is also included in the conditional variance, but are not shown in consideration of space. 
Table 4 - Robustness and Sensitivity Analysis - Global Economic Conditions

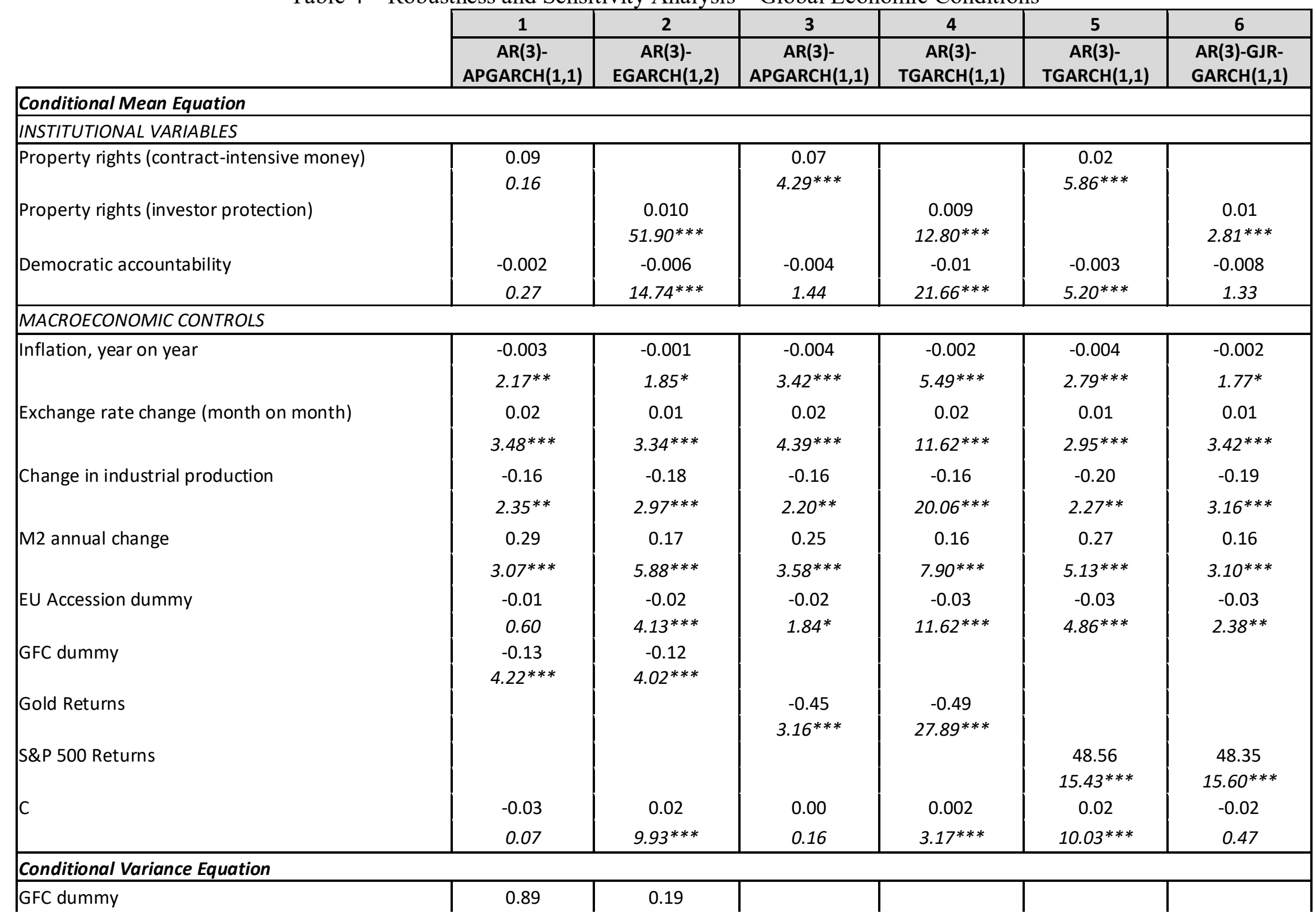




\begin{tabular}{|c|c|c|c|c|c|c|}
\hline & 1 & 2 & 3 & 4 & 5 & 6 \\
\hline & $\begin{array}{c}\text { AR(3)- } \\
\text { APGARCH(1,1) }\end{array}$ & $\begin{array}{c}\text { AR(3)- } \\
\text { EGARCH(1,2) }\end{array}$ & $\begin{array}{c}\text { AR(3)- } \\
\text { APGARCH(1,1) } \\
\end{array}$ & $\begin{array}{c}\text { AR(3)- } \\
\operatorname{TGARCH}(1,1) \\
\end{array}$ & $\begin{array}{c}\text { AR(3)- } \\
\operatorname{TGARCH}(1,1)\end{array}$ & $\begin{array}{l}\text { AR(3)-GJR- } \\
\text { GARCH(1,1) }\end{array}$ \\
\hline \multirow[b]{2}{*}{ Gold Volatility } & $4.48^{* * *}$ & $6.28^{* * *}$ & & & & \\
\hline & & & $\begin{array}{c}-0.001 \\
0.61\end{array}$ & $\begin{array}{c}-0.003 \\
0.90\end{array}$ & & \\
\hline \multirow[t]{2}{*}{ S\&P 500 Volatility } & & & & & 70.08 & 70.13 \\
\hline & & & & & $11.27^{* * *}$ & $11.48^{* * *}$ \\
\hline \multirow[t]{2}{*}{ Property Rights (CIM) } & 0.51 & & 0.75 & & -0.11 & \\
\hline & 0.74 & & 1.16 & & 0.12 & \\
\hline \multirow[t]{2}{*}{ SD of Property Rights (CIM), 6 months } & -6.93 & & -1.72 & & -19.20 & \\
\hline & 0.85 & & 0.23 & & 1.50 & \\
\hline \multirow[t]{2}{*}{ Property Rights (Investor Protection) } & & 0.008 & & 0.07 & & 0.001 \\
\hline & & $2.17^{* *}$ & & $1.90^{*}$ & & 0.04 \\
\hline \multirow[t]{2}{*}{ SD of Property Rights (Investor Protection), 6 months } & & 0.01 & & 0.20 & & 0.12 \\
\hline & & 0.25 & & 0.99 & & 0.79 \\
\hline \multirow[t]{2}{*}{ Democratic Accountability } & -0.04 & -0.006 & -0.05 & -0.09 & -0.08 & -0.07 \\
\hline & 1.21 & 1.29 & $1.84^{*}$ & $1.92 *$ & $1.94 *$ & $1.80^{*}$ \\
\hline \multirow[t]{2}{*}{ SD of Democratic Accountability, 6 months } & 0.71 & 0.18 & 0.59 & 1.13 & 1.19 & 1.13 \\
\hline & $2.42^{* *}$ & $2.59^{* * *}$ & $2.03^{* *}$ & $3.23^{* * *}$ & $3.30 * * *$ & $4.03^{* * *}$ \\
\hline \multirow[t]{2}{*}{ Leverage effect } & 0.06 & 2.92 & 0.06 & 0.04 & 0.08 & 0.20 \\
\hline & $3.95^{* * *}$ & $14.12 * * *$ & $5.18^{* * *}$ & $6.52^{* * *}$ & $3.45^{* * *}$ & $3.52^{* * *}$ \\
\hline n & 3152 & 3412 & 3152 & 3412 & 3152 & 3412 \\
\hline Macro volatility controls in variance equation? & yes & yes & yes & yes & yes & yes \\
\hline Log Likelihood & -1463.917 & 1550.15 & -1496.206 & -1582.80 & -1317.78 & -1390.66 \\
\hline AIC & 0.9450 & 0.9230 & 0.9652 & 0.9419 & 0.8514 & 0.8292 \\
\hline Distribution & Student's T & Student's T & Student's T & Student's T & Student's T & Student's T \\
\hline
\end{tabular}

Dependent variable is log of stock market returns, with model choice shown above each column of results. Note: absolute values of t-stats are under the coefficients, with * signifying significance at the $10 \%$ level, ** at 5\% and *** at the $1 \%$ level. The complete set of macroeconomic variables utilized in the conditional mean equation is also included in the conditional variance, but are not shown in consideration of space. 
Table 5 - Realized Volatility v. Institutional Volatility

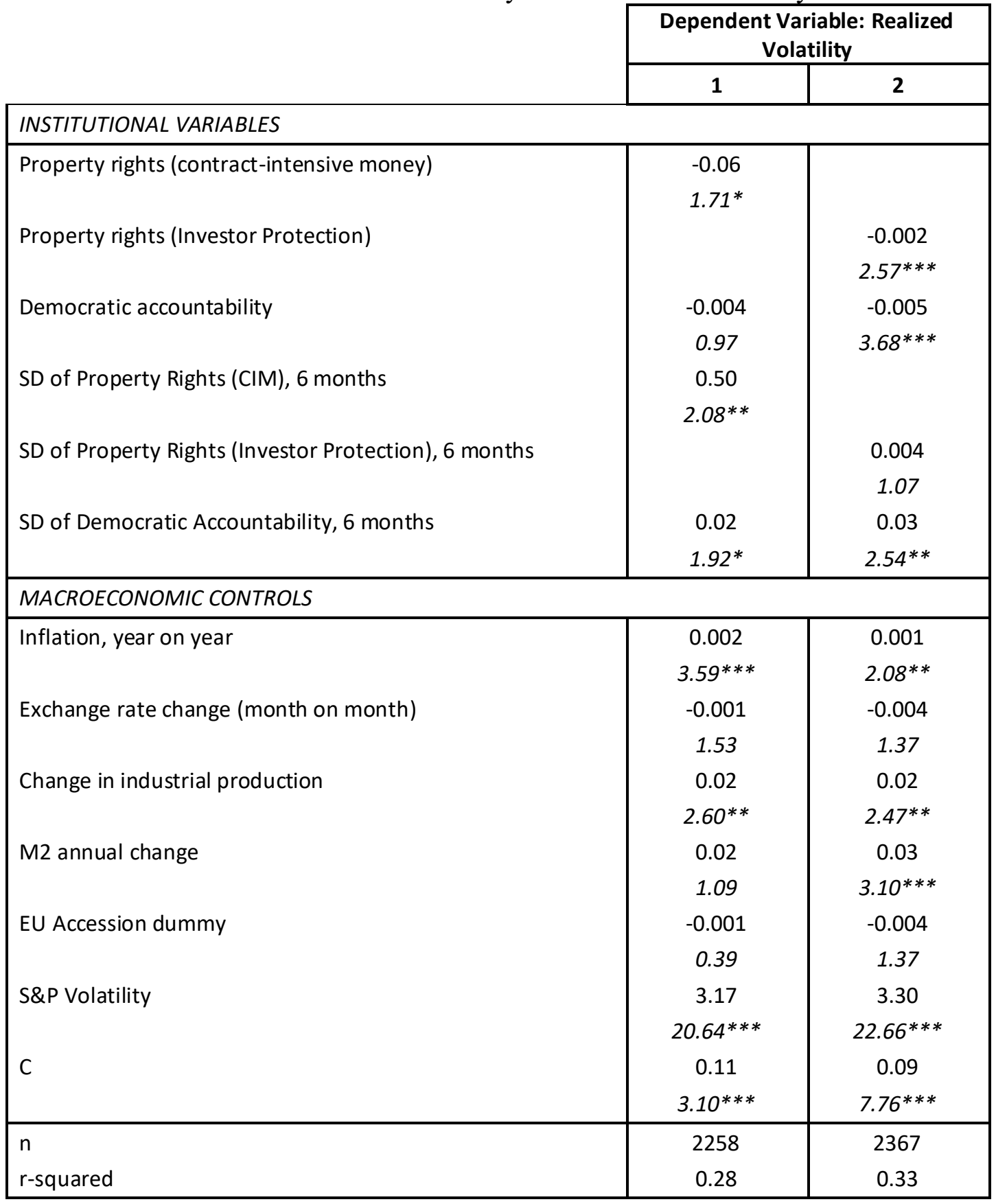

OLS model with Driscoll-Kraay standard errors and country fixed-effects measuring realized volatility (left-hand side) as a function of the full robustness model of Table 4 (right-hand side variables). Note: absolute values of $t$-stats are under the coefficients, with * signifying significance at the $10 \%$ level, $* *$ at $5 \%$ and $* * *$ at the $1 \%$ level. 


\section{ACKNOWLEDGEMENTS}

I would like to thank the Bank of Finland Institute for Economies in Transition (BOFIT) for supporting this research, and especially Laura Solanko for her encouragement and comments. The key driver behind the paper was Nauro Campos, who supported the development of the paper, provided excellent comments at every stage, and authored the "spiritual father" of this analysis. I also thank Mikhail Volkov and Anne-Christin Winkler for excellent and persistent research assistance throughout the many years it took to create this paper, as well as participants at the "Economic Challenges in Enlarged Europe" Conference in Tallinn, Estonia (June 16-18, 2013) for their comments, especially Karsten Staehr, Josef Brada, and Anna Zamojska. Additional thanks go to two anonymous referees, Ruben Enikolopov, participants at the ACES poster session during the ASSA Conference 2014 (including Ali M. Kutan), Geert Bekaert for later comments, and Matti

Keloharju of Aalto University for his encouragement to publish in a top journal. All errors remain my own.

\section{REFERENCES}

Acemoglu, D., and Johnson, S. (2005). Unbundling institutions. Journal of Political Economy, 113(5), 949-995.

Aizenman, J., \& Marion, N. P. (1993). Policy Uncertainty, Persistence and Growth*. Review of International Economics, 1(2), 145-163.

Akitoby, B., \& Stratmann, T. (2010). The value of institutions for financial markets: evidence from emerging markets. Review of World Economics, 146(4), 781-797.

Ali, F. A., Fiess, N., and MacDonald, R. (2010). Do institutions matter for foreign direct investment? Open Economies Review, 21(2), 201-219.

Andersen, T. G. (1996). Return volatility and trading volume: An information flow interpretation of stochastic volatility. The Journal of Finance, 51(1), 169-204.

Andersen, T. G., Bollerslev, T., Diebold, F. X., and Labys, P. (2003). Modeling and Forecasting Realized Volatility. Econometrica, 71(2), 579-625

Andrianaivo, M., and Yartey, C.A. (2009). Understanding the Growth of African Financial Markets. IMF Working Paper 09/182.

Angelopoulos, K., Economides, G., and Vassilatos, V. (2011). Do institutions matter for economic fluctuations? Weak property rights in a business cycle model for Mexico. Review of Economic Dynamics, 14(3), 511-531.

Asoni, A. (2008). Protection of property rights and growth as political equilibria. The Journal of Economic Surveys, 22(5), 953-987. 
Asteriou, D., and Price, S.G. (2001). Political Instability and Economic Growth: UK Time Series Evidence. Scottish Journal of Political Economy, 48, 244- 249.

Baillie, R. T., and DeGennaro, R. P. (1990). Stock returns and volatility. Journal of Financial and Quantitative Analysis, 25(02), 203-214.

Baker, S. R., Bloom, N., and Davis, S. J. (2016). Measuring economic policy uncertainty. The Quarterly Journal of Economics, 131(4), 1593-1636.

Baumol, W.J. (1990). Entrepreneurship: productive, unproductive and destructive. Journal of Political Economy, 98 (5), 893-921.

Beck, T., \& Levine, R. (2008). Legal institutions and financial development. Heidelberg: Springer Berlin, 251-278.

Beine, M., Cosma, A., and Vermeulen, R. (2010). The dark side of global integration: Increasing tail dependence. Journal of Banking \& Finance, 34(1), 184-192.

Beirne, J., Caporale, G. M., Schulze-Ghattas, M., and Spagnolo, N. (2009) Volatility Spillovers and Contagion from Mature to Emerging Stock Markets. European Central Bank (ECB) Working Paper No. 1113, November.

Bekaert, G., and Harvey, C. R. (1997). Emerging equity market volatility. Journal of Financial economics, 43(1), 29-77.

Beltratti, A., and Morana, C. (2006). Breaks and persistency: macroeconomic causes of stock market volatility. Journal of Econometrics, 131(1), 151-177.

Berggren, N., Bergh, A., and Bjørnskov, C. (May 2017). The Growth Effects of Institutional Instability. Journal of Institutional Economics, 8(2), 187-224.

Besley, T. (1995). Property Rights and Investment Incentives: Theory and Evidence from Ghana. Journal of Political Economy, 103, 903-937.

Białkowski, J., Gottschalk, K., and Wisniewski, T.P. (2008). Stock market volatility around national elections. Journal of Banking and Finance, 32(9), 1941-1953.

Bollerslev, T. (1987). A conditional heteroskedastic time series model for speculative price and rate of return. Review of Economics and Statistics, 9, 542-547.

Bollerslev, T. and Zhou, H. (2006). Volatility Puzzles: A Simple Framework for Gauging ReturnVolatility Regressions. Journal of Econometrics, 131(1), 123-156.

Bollerslev, T, Engle, R.F, and Nelson, D.B. (1994). ARCH models. In Handbook of Econometrics (Vol. IV), Engle RF, McFadder DL (eds). Elsevier Science: Amsterdam. 
Boutchkova, M., Doshi, H., Durnev, A., and Molchanov, A. (May 2017). Precarious politics and return volatility. Review of Financial Studies, 25(4), 1111-1154.

Boyd, J.H., Levine, R., and Smith, B.D. (2001). The impact of inflation on financial sector performance, Journal of Monetary Economics, 47(2), 221-248.

Brogaard, J. and Detzel, A. (2015). The asset-pricing implications of government economic policy uncertainty. Management Science, 61(1), 3-18.

Brown, R. P., Carmignani, F., and Fayad, G. (2013). Migrants' Remittances and Financial Development: Macro-and Micro-Level Evidence of a Perverse Relationship. The World Economy, 36(5), 636-660.

Busse, M., and Hefeker, C. (2007). Political risk, institutions and foreign direct investment. European Journal of Political Economy, 23(2), 397-415.

Campos, N. F., and Karanasos, M. (2008). Growth, Volatility, and Political Instability: Non-Linear Time-Series Evidence for Argentina, 1896-2000. Economics Letters, 100, 135-137.

Campos, N.F., Karanasos, M., and Tan, B. (May 2017). Two to tangle: Financial development, political instability and economic growth in Argentina. Journal of Banking \& Finance, 36(1), 290304.

Catrinescu, N., Leon-Ledesma, M., Piracha, M., and Quillin, B. (2009). Remittances, institutions, and economic growth. World Development, 37(1), 81-92.

Cermeno, R., and Grier, K. (2006). Conditional heteroskedasticity and cross-sectional dependence in panel data: an empirical study of inflation uncertainty in the G-7 countries. In: B. Baltagi (ed.), Panel Data Econometrics: Theoretical Contributions and Empirical Applications. Springer: New York, 259-278.

Chen, N. F., Roll, R., and Ross, S. A. (1986). Economic forces and the stock market. Journal of Business, 59, 383-403.

Chiang, T. C., and Doong, S. C. (2001). Empirical analysis of stock returns and volatility: Evidence from seven Asian stock markets based on TAR-GARCH model. Review of Quantitative Finance and Accounting, 17(3), 301-318.

Chinn, M. D. and Ito, H. (2006). What matters for financial development? Capital controls, institutions, and interactions. Journal of Development Economics, 81(1), 163-192.

Christensen, B. J., \& Prabhala, N. R. (1998). The relation between implied and realized volatility. Journal of Financial Economics, 50(2), 125-150.

Christiansen, C., Schmeling, M., and Schrimpf, A. (May 2017). A comprehensive look at financial volatility prediction by economic variables. Journal of Applied Econometrics, 27(6), 956-977. 
Christie, A. A. (1982). The stochastic behaviour of common stock variances: value, leverage and interest rate effects. Journal of Financial Economics, 10(4), pp 407-432.

Chung, C. C., and Beamish, P. W. (2005). The Impact of Institutional Reforms on Characteristics and Survival of Foreign Subsidiaries in Emerging Economies. Journal of Management Studies, 42(1), 35-62.

Claessens, S. and Laeven, L. (2003). Financial Development, Property Rights, and Growth. Journal of Finance, 58(6), 2401-2436.

Clague, C., Keefer, P., Knack, S., and Olson, M. (1996). Property and contract rights in autocracies and democracies. Journal of Economic Growth, 1(2), 243-276.

(1999). Contract-intensive money: contract enforcement, property rights, and economic performance. Journal of Economic Growth, 4(2), 185-211.

Compton, R. A., and Giedeman, D. C. (2011). Panel evidence on finance, institutions and economic growth. Applied Economics, 43(25), 3523-3547.

Corradi, V., Distaso, W., and Mele, A. (2013). Macroeconomic Determinants of Stock Volatility and Volatility Premiums. Journal of Monetary Economics, 60, 203-220.

Darvas, Z.(May 2017). Real effective exchange rates for 178 countries: A new database. Working Paper May 2017/06, Bruegel.

De Long, J. B., Shleifer, A., Summers, L. H., and Waldmann, R. J. (1990). Noise Trader Risk in Financial Markets. The Journal of Political Economy, 98(4), 703-738.

Demirgüç-Kunt, A., and Levine, R. (1996). Stock Market Development and Financial Intermediaries: Stylized Facts. The World Bank Economic Review, 10 (2), 291-321.

Ding, Z., Granger, C.W.J., and Engle, R. (1993). A Long Memory Property of Stock Market Returns and a New Model. Journal of Empirical Finance, 1, 83-106.

Dollar, D., and Kraay, A. (2003). Institutions, trade, and growth. Journal of Monetary Economics, 50(1), 133-162.

Driscoll, J. C., and Kraay, A. C. (1998). Consistent covariance matrix estimation with spatially dependent panel data. The Review of Economics and Statistics, 80(4), 549-560.

Durham, J.B. (2002). The effects of stock market development on growth and private investment in lower-income countries. Emerging Markets Review, 3, 211-232.

Durnev, A., Errunza, V., \& Molchanov, A. (2009). Property rights protection, corporate transparency, and growth. Journal of International Business Studies,40(9), 1533-1562. 
Dutta, N., and Roy, S. (2011). Foreign direct investment, financial development and political risks. The Journal of Developing Areas, 44(2), 303-327.

Engle, R. F. (1982). Autoregressive Conditional Heteroskedasticity with Estimates of the Variance of U.K. Inflation. Econometrica, 50(4), 987-1008.

Engle, R.F., and Ng, V.K. (1993). Measuring and Testing the Impact of News on Volatility. The Journal of Finance, 48(5), 1749-1778.

Engle, R.F., and Rangel, J.G. (2008). The Spline-GARCH Model for Low-Frequency Volatility and Its Global Macroeconomic Causes. Review of Financial Studies, 21 (3), 1187-1222.

Engle, R. F., Ghysels, E., and Sohn, B. (2013). Stock market volatility and macroeconomic fundamentals. Review of Economics and Statistics, 95(3), 776-797.

Errunza, V., and Hogan, K. (1998). Macroeconomic determinants of European stock market volatility. European Financial Management, 4(3), 361-377.

Ferderer, J. P., and Zalewski, D. A. (1994). Uncertainty as a propagating force in the Great Depression. The Journal of Economic History, 54(4), 825-849.

Flannery, M. J., and Protopapadakis, A. A. (2002). Macroeconomic factors do influence aggregate stock returns. Review of Financial Studies, 15(3), 751-782.

Fleming, J. (1998). The quality of market volatility forecasts implied by S\&P 100 index option prices. Journal of Empirical Finance, 5(4), 317-345.

Forbes, K. J., and Rigobon, R. (2002). No contagion, only interdependence: measuring stock market comovements. The Journal of Finance, 57(5), 2223-2261.

French, K. R., and Roll, R. (1986). Stock return variances: The arrival of information and the reaction of traders. Journal of Financial Economics, 17(1), 5-26.

Gabaix, X., Gopikrishnan, P., Plerou, V., and Stanley, H. E. (2006). Institutional investors and stock market volatility. The Quarterly Journal of Economics, 121(2), 461-504.

Gallo, A. A., and Alston, L. J. (2008). Argentina's Abandonment of the Rule of Law and its Aftermath. Washington University Journal of Law \& Policy, 26, 153-182.

Garcia, V.F., and Liu, L. (1999). Macroeconomic Determinants of Stock Market Development. Journal of Applied Economics, 2(1), 29-59.

Gilles, R. P., Lazarova, E. A., \& Ruys, P. H. (2015). Stability in a network economy: The role of institutions. Journal of Economic Behavior \& Organization, 119, 375-399. 
Glosten, L. R., Jagannathan, R., and Runkle, D. E. (1993). "On the relation between the expected value and the volatility of the nominal excess return on stocks," Journal of Finance, 45(5), 17791801.

Gourinchas, P-O., R.Valdes, and O. Landerretche. (2001). Lending Booms: Some Stylized Facts. NBER Working Paper 8249, April.

Haber, S.H. (2008). Political institutions and financial development: evidence from the political economy of bank regulation in Mexico and the United States. In Haber, S.H., North, D.C., and Weingast, B. (eds.), Political Institutions and Financial Development. Palo Alto, CA: Stanford University Press, pp 10-59.

Hartwell, C.A. (2013). Institutional Barriers in the Transition to Market: Explaining Performance and Divergence in Transition Economies, London: Palgrave Macmillan.

(2014). Do (Successful) Stock Exchanges Support or Hinder Institutions in Transition Economies? Cogent Economics \& Finance, 2(1), 946620.

(2017). The effect of political volatility on capital markets in EU accession and neighborhood countries. Journal of Economic Policy Reform, forthcoming, https://doi.org/10.1080/17487870.2017.1311793.

Hayo, B., and Kutan, A.M. (2005). IMF-Related News and Emerging Financial Markets. Journal of International Money and Finance, 24, 1126-1142.

Henisz, W. (2004). Political Institutions and Policy Volatility. Economics and Politics, 16(1), 127.

Hsing, Y. and Hsieh, W-J. (May 2017). Impacts of Macroeconomic Variables on the Stock Market Index in Poland: New Evidence. Journal of Business Economics and Management, 13, 334-343.

Jayasuriya, S. (2005). Stock market liberalization and volatility in the presence of favorable market characteristics and institutions. Emerging Markets Review, 6(2), 170-191.

Johnson, S., McMillan, J., and Woodruff, C. (2002). Property Rights and Finance. American Economic Review, 92(5), 1335-1356.

Keefer, P. (2008). Beyond legal origin and checks and balances: Political credibility, citizen information and financial sector development. In Haber, S.H., North, D.C., and Weingast, B. (eds.), Political Institutions and Financial Development. Palo Alto, CA: Stanford University Press, pp. 125-155.

King, M. A., and Wadhwani, S. (1990). Transmission of volatility between stock markets. Review of Financial Studies, 3(1), 5-33. 
Klomp, J., and de Haan, J. (2009). Political Institutions and Economic Volatility. European Journal of Political Economy, 25, 311-326.

Knack, S. (1996). Institutions and the Convergence Hypothesis: The Cross-National Evidence. Public Choice, 87(3/4), 207-228.

Knack, S., and Keefer, P. (1995). Institutions and economic performance: cross-country tests using alternative institutional measures. Economics \& Politics, 7(3), 207-227.

Knack, S., Kugler, M., and Manning, N. (2003). Second-generation governance indicators. International Review of Administrative Sciences, 69(3), 345-364.

Laurent, S. (2004). Analytical derivates of the APARCH model. Computational Economics, 24(1), 51-57.

Leiss, M., Nax, H. H., \& Sornette, D. (2015). Super-exponential growth expectations and the global financial crisis. Journal of Economic Dynamics and Control, 55, 1-13.

Lin, C., Lin, P., \& Zou, H. (May 2017). Does property rights protection affect corporate risk management strategy? Intra-and cross-country evidence. Journal of Corporate Finance, 18(2), 311-330.

Ludvigson, S. C., and $\mathrm{Ng}$, S. (2007). The empirical risk-return relation: a factor analysis approach. Journal of Financial Economics, 83(1), 171-222.

Malik, F. (2011). Estimating the impact of good news on stock market volatility. Applied Financial Economics, 21(8), 545-554.

Merton, R. (1980). On estimating the expected return on the market: An explanatory investigation. Journal of Financial Economics, 8(4), 323-361.

Miletkov, M., and Wintoki, M.B. (2009). Legal institutions, democracy and financial sector development. In Hirschey, M. et al. (eds.), Corporate Governance and Firm Performance (pp. 171-196). Bingley, UK: Emerald Group Publishing Limited.

(2017). Financial development and the evolution of property rights and legal institutions. Emerging Markets Review, 13(4), 650-673.

Morck, R., Yeung, B., and Yu, W. (2000). The information content of stock markets: why do emerging markets have synchronous stock price movements? Journal of Financial Economics, 58(1), 215-260.

Nelson, D.B. (1991). Conditional heteroskedasticity in asset returns: a new approach. Econometrica, 59, 347-370. 
Nikkinen, J., Omran, M. M., Sahlström, P., and Äijö, J. (2008). Stock returns and volatility following the September 11 attacks: Evidence from 53 equity markets. International Review of Financial Analysis, 17(1), 27-46.

Panetta, F. (2002). The Stability of the Relation between the Stock Market and Macroeconomic Forces. Economic Notes, 31(3), 417-450.

Pástor, L., and Veronesi, P. (2013). Political uncertainty and risk premia. Journal of Financial Economics, 110(3), 520-545.

Paye, B. S. (May 2017). 'Déjà vol': Predictive regressions for aggregate stock market volatility using macroeconomic variables. Journal of Financial Economics, 106(3), 527-546.

Perry, P. (1982). The time-variance relationship of security returns: Implications for the returngenerating stochastic process. Journal of Finance, 37(3), 857-870.

Rajan, R. G., \& Zingales, L. (2003). The great reversals: the politics of financial development in the twentieth century. Journal of Financial Economics, 69(1), 5-50.

Rodrik, D. (1991). Policy uncertainty and private investment in developing countries. Journal of Development Economics, 36(2), 229-242.

Roodman, D. (2009). A Note on the Theme of Too Many Instruments. Oxford Bulletin of Economics and Statistics, 71(1), 135-158.

Schwert, G. W. (1989). Why does stock market volatility change over time? The Journal of Finance, 44(5), 1115-1153.

Stern, E., Sundelius, B., Nohrstedt, D., Hansén, D., Newlove, L., and Hart, P. T. (2002). Crisis management in transitional democracies: The Baltic experience. Government and Opposition, 37(4), 524-550.

Svensson, J. (1998). Investment, property rights and political instability: Theory and evidence. European Economic Review, 42(7), 1317-1341.

Tauchen, G. (1986). Statistical properties of generalized method-of-moments estimators of structural parameters obtained from financial market data. Journal of Business \& Economic Statistics, 4(4), 397-416.

Torstensson, J. (1994). Property Rights and Economic Growth: An Empirical Study. Kyklos, 47(2), 231-247.

Vogelsang, T. J. (May 2017). Heteroskedasticity, autocorrelation, and spatial correlation robust inference in linear panel models with fixed-effects. Journal of Econometrics, 166(2), 303-319. 
Voigt, S. (2013). How (Not) to Measure Institutions. Journal of Institutional Economics, 9(1), 126.

Wu, H.X., and Shea, E.Y.P. (2011). Explaining the China Puzzle: High Growth and Low Volatility in the Absence of Healthy Financial Institutions, Paper prepared for EcoMod2011, Azores, Portugal, June 29-July 1, available on-line at: http://ecomod.net/system/files/WuShea EcoMod2011.pdf.

Yang, B. (2011a). Does democracy foster financial development? An empirical analysis. Economics Letters, 112(3), 262-265.

(2011b). Political democratization, economic liberalization, and growth volatility. Journal of Comparative Economics, 39(2), 245-259.

Zakoian, J.M. (1994). Threshold Heteroskedastic Models. Journal of Economic Dynamics and Control, 18(5), 931-955.

Zumbach, G. (2000). The pitfalls in fitting GARCH $(1,1)$ processes. Advances in Quantitative Asset Management, 179-200. 


\section{DATA APPENDIX}

Table A.1 - Underlying Data Description and Sources

\begin{tabular}{|c|c|c|}
\hline Data & Description & Source \\
\hline \multicolumn{3}{|l|}{ Financial Market Variables } \\
\hline \multicolumn{3}{|l|}{ Stock market data } \\
\hline Belarus & Belarus Stock Exchange Index, 2005-May 2017 & CEIC database and personal correspondence \\
\hline Bosnia & Sarajevo Stock Exchange BIFX Index, 2006-May 2017 & Sarajevo Stock Exchange website \\
\hline Bulgaria & SOFIX Index, 2000-May 2017 & Bulgarian Stock Exchange website \\
\hline Croatia & CROBEX Stock Market Index, 1997-May 2017 & Datastream \\
\hline Czech Republic & Prague Stock Exchange PX Index, 1994-May 2017 & Bloomberg \\
\hline Estonia & $\begin{array}{l}\text { Talinn Stock Market Index; TALSE 1996-2004, OMX } \\
\text { 2004-May } 2017\end{array}$ & Datastream \\
\hline Hungary & Budapest Stock Exchange BUX Index, 1997-May 2017 & Bloomberg \\
\hline Kazakhstan & MSCI Kazakhstan Total Market Index, 2000-May 2017 & Datastream \\
\hline Kyrgyz Republic & Kyrgyz Stock Exchange Share Price Index, 2009-May 2017 & $\begin{array}{c}\text { Kyrgyz Stock Exchange website, personal } \\
\text { correspondence }\end{array}$ \\
\hline Latvia & Riga Stock Exchange OMX Index, 2000-May 2017 & NASDAQ OMX website \\
\hline Lithuania & Vilnius Stock Exchange OMX Index, 2000-May 2017 & NASDAQ OMX website \\
\hline Macedonia & Macedonian Stock Exchange MBI Index, 2005-May 2017 & Datastream \\
\hline Mongolia & $\begin{array}{l}\text { Mongolian Stock Exchange MSE Top-20 Index, 1995-May } \\
2017\end{array}$ & CEIC database \\
\hline Poland & $\begin{array}{l}\text { Warsaw Stock Exchange WIG Total Stock Index, 1991- } \\
\text { May } 2017\end{array}$ & Bloomberg \\
\hline Romania & $\begin{array}{l}\text { Bucharest Stock Exchange Trading Index (BET), 1997-May } \\
2017\end{array}$ & Datastream \\
\hline Russia & Moscow Exchange RTS Index, 1995-May 2017 & Datastream \\
\hline Serbia & MSCI Serbia Stock Market Index, 2008-May 2017 & Datastream \\
\hline
\end{tabular}




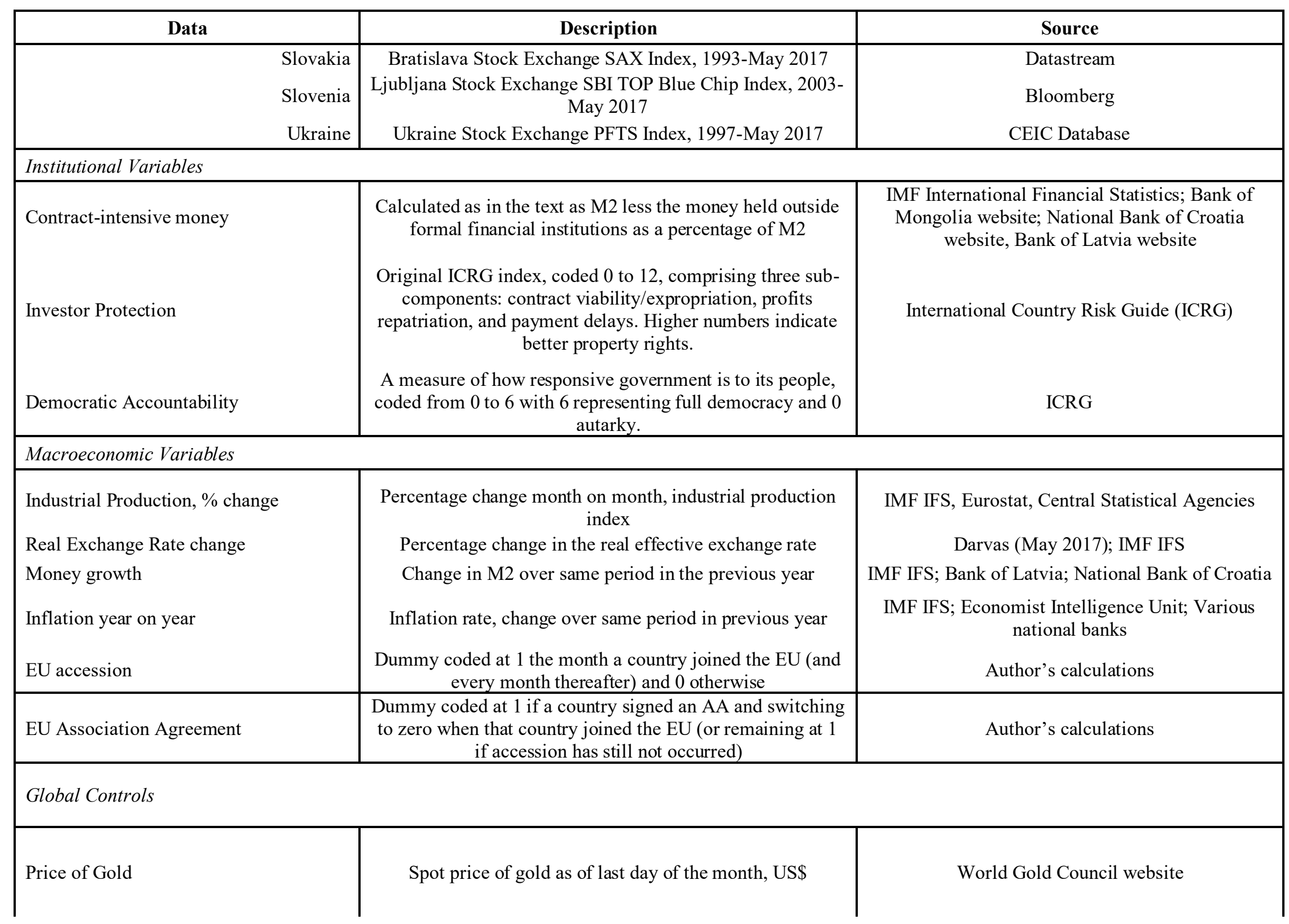




\begin{tabular}{|l|c|c|}
\hline \multicolumn{1}{|c|}{ Data } & Description & Source \\
\hline Gold Price Volatility & $\begin{array}{c}\text { Month-to-month volatility of returns to gold holdings, } \\
\text { computed as square of log returns over the month. }\end{array}$ & Author's calculations \\
S\&P 500 Index & $\begin{array}{c}\text { Difference between close of day price and previous day's } \\
\text { closing price. }\end{array}$ & Bloomberg \\
S\&P Volatility & Squared sum of log returns monthly. & Autculations \\
\hline
\end{tabular}




\section{A Note on the Property Rights Measures}

The two measures for property rights, given that they measure different facets of property rights protection, need not overlap perfectly. In fact, a simple Spearman correlation test between the two indicators shows that there is mildly strong, but not perfect, correlation between the two variables $(\mathrm{r}=0.2709)$. Taken as a country-by-country pairwise correlation, there is substantial divergence between the two variables, from a low of -0.6562 for Bulgaria (meaning that, as legislative frameworks get better, there is no guarantee that property rights did) to a high of 0.8571 for Estonia (signaling that administrative implementation of rights moved in tandem with the legal framework). In this sense, the two variables are used to bracket the concept of property rights econometrically: either we observe the inputs of property rights (laws) or we observe its outputs (more confidence in banking institutions), but we never actually observe property rights. This reality means that inputs and outputs need not necessarily match, especially true in a transition context.

Moreover, it is possible that perhaps one or both of these property rights indicators could capture general uncertainty in the economy or macroeconomic trends and not property rights per se. ${ }^{10}$ However, this also appears not to be the case in this dataset, as the pooled correlations between property rights and the market returns metric noted above is -0.0007 for contract-intensive money and -0.0054 for investor protection, suggesting instead an almost wholly inconsequential relationship between property rights and market returns. Similar but slightly stronger negative correlations are obtained when utilizing realized volatility (approximately -0.20 for both indicator),

\footnotetext{
10 Thanks are due to a thorough anonymous referee who pointed this out.
} 
adding more credibility to these indicators capturing actual property rights rather than simply macroeconomic conditions or volatility. ${ }^{11}$

\section{Macroeconomic Controls}

Due to the difficulties of finding monthly macroeconomic data in transition economies, the set of controls for the regressions shown in the paper is necessarily somewhat parsimonious; in one sense, this is hopefully forgivable, as the purpose of this paper is not to reconfirm previous results regarding the effects of macroeconomic variables. But as a full picture of institutional volatility is not complete without these established determinants of volatility, in addition to the variables shown above, various other macroeconomic indicators were attempted in both this paper and the earlier, working version of this research. Measures of financial depth, financial liberalization, interest rates, and openness were contemplated (and constructed) as a control for this examination, but the incredible paucity of monthly data in these areas, especially in the early years of transition, also made for a rather significant loss of observations, with little improvement of the model. Finally, similar issues were found while searching for a complete set of controls as in Paye (2012), in regard to highly detailed firm or bank data; much of the data was simply not feasible for this exercise, as such data was impossible to come by at such a high frequency in the early years of transition. Some data would have been available for only the "standout" countries (Poland and the Czech Republic, for example), introducing a measure of reverse causality into the analysis, i.e. the only countries able to have a full complement of macroeconomic controls were also those with the best-performing institutions.

\footnotetext{
${ }^{11}$ The institutional volatility metrics, described below, also have little to no correlation with the financial volatility or market return indicators. Six-month volatility of contract-intensive money correlates only at 0.28 with (realized) market volatility and 0.04 with market returns, while the measure of investor protection volatility correlates at between -0.01 and -0.02 for market volatility and market returns.
} 
